\title{
COVID-19: Pandemic surgery guidance
}

Björn L.D.M. Brücher ${ }^{1,2,3,{ }^{*}}$, Giuseppe $\mathrm{Nigri}^{4}$, Andrea Tinelli ${ }^{5}$, Jose Florencio F. Lapeña Jr. ${ }^{6}$, Eloy Espin-Basany ${ }^{7}$, Paolo Macri ${ }^{8}$, Edouard Matevossian ${ }^{9}$, Sergio Ralon ${ }^{10}$, Ray Perkins ${ }^{11}$, Rainer Lück ${ }^{12}$, Rainer Kube ${ }^{3}$, Jose MC da Costa ${ }^{13}$, Yoav Mintz ${ }^{14}$, Mesut Tez ${ }^{15}$, Sixtus Allert ${ }^{16}$, Selman Sökmen ${ }^{17}$, Arkadiusz Spychala ${ }^{18}$, Bruno Zilberstein ${ }^{19}$, Frank Marusch ${ }^{20}$, Mohammad Kermansaravi ${ }^{21}$, Witold Kycler ${ }^{18}$, Diego Vicente ${ }^{22}$, Michael A. Scherer ${ }^{23}$, Avraham Rivkind ${ }^{14}$, Nelson Elias ${ }^{24}$, Grzegorz Wallner ${ }^{25}$, Franco Roviello ${ }^{26}$, Lúcio Lara Santos ${ }^{27}$,

Raimund J.C. Araujo Jr. ${ }^{28}$, Amir Szold ${ }^{29}$, Raúl Oleas ${ }^{30}$, Marjan Slak Rupnik ${ }^{1,2,31}$, Jochen Salber ${ }^{32}$, Ijaz S. Jamall ${ }^{1,2,33}$, Alexander Engel ${ }^{34}$, for the Pandemic Surgery Guidance Consortium (PSGC)

${ }^{1}$ Theodor-Billroth-Akademie ${ }^{\circledR}$, Germany, USA

${ }^{2}$ INCORE, International Consortium of Research Excellence of the Theodor-Billroth-Academy ${ }^{\circledR}$, Germany, USA

${ }^{3}$ Department of Surgery, Carl-Thiem-Klinikum, Cottbus, Germany

${ }^{4}$ Department of Medical and Surgical Sciences and Translational Medicine, Sapienza University of Rome, St. Andrea University Hospital, Rome, Italy

${ }^{5}$ Department of Obstetrics and Gynecology, Veris delli Ponti Hospital, Scorrano, Lecce, Italy

${ }^{6}$ Department of Otorhinolaryngology, College of Medicine-Philippine General Hospital, University of the Philippines Manila, Manila, Philippines

${ }^{7}$ Department of Surgery, Vall d'Hebron, Universitat Autonoma de Barcelona, Barcelona, Spain

${ }^{8}$ Department of Thoracic Surgery, Istituto Clinico Humanitas CCO, Catania, Italy

${ }^{9}$ Department of Surgery, Klinikum rechts der Isar, Technical University of Munich, Munich, Germany

${ }^{10}$ Department of Surgery, Hospital General San Juan de Dios, Universidad de San Carlos de Guatemala, Calle, Guatemala

${ }^{11}$ New Liberty Proteomics Corporation, New Liberty, KY, USA

${ }^{12}$ Department of Surgery, Sana Klinikum Hameln-Pyrmont, Hameln, Germany

${ }^{13}$ Centro de Imunologia e Biologia Parasitária, Scientific Director of Center for Study in Animal Science, ICETA, University of Porto, Porto, Portugal

${ }^{14}$ Department of General Surgery and Shock Trauma Unit, Hadassah-Hebrew University Medical Center, Ein Kerem, Jerusalem, Israel

${ }^{15}$ Department of Surgery, Ankara Numune Hospital, Ankara, Turkey

${ }^{16}$ Department of Plastic, Aesthetic and Hand Surgery, Sana Klinikum Hameln-Pyrmont, Hameln, Germany

${ }^{17}$ Colorectal and Pelvic Surgery, Dokuz Eylül University Hospital, Izmir, Turkey

${ }^{18}$ Gastrointestinal Surgical Oncology Department, Greater Poland Cancer Centre, Poznan, Poland

${ }^{19}$ Cancer Institute, Hospital das Clínicas, School of Medicine, University of São Paulo, São Paulo, Brazil

${ }^{20}$ Department of Surgery, Ernst von Bergmann Hospital, Potsdam, Germany

${ }^{21}$ Minimally Invasive Surgery Research Center, Iran University of Medical Sciences, Tehran, Iran

${ }^{22}$ Department of Surgery, Uniformed Services University of the Health Sciences \& the Walter Reed National Military Medical Center, Bethesda, MD, USA

${ }^{23}$ Department for Orthopedics and Trauma Surgery, Helios Amper Hospital Dachau, Dachau, Germany

${ }^{24}$ Orthopedic Department, Vila Velha Hospital, Vila Velha, Espirito Santo, Brazil

${ }^{25}$ Department of Surgery, Medical University of Lublin, Lublin, Poland

${ }^{26}$ Surgical Oncology, University of Siena, Siena, Italy

${ }^{27}$ Surgical Oncology Department - Portuguese Institute of Oncology, Porto, Portugal

${ }^{28}$ Department of Surgery, Federal University of Piauí, Teresina, Piauí, Brazil

${ }^{29}$ Assia Medical Group, Assuta Medical Center, Tel Aviv, Israel

${ }^{30}$ Surgical Oncology, HPB and Liver Transplantation, Ecuadorian Cancer Institute, Quito, Ecuador

${ }^{31}$ Center for Physiology and Pharmacology, Medical University of Vienna, Vienna, Austria

${ }^{32}$ Department of Surgery, UK Knappschaftskrankenhaus, Ruhr University, Bochum, Germany

${ }^{33}$ Risk-Based Decisions Inc., Sacramento, CA, USA

${ }^{34}$ Department of Colorectal Surgery, Royal North Shore Hospital, University of Sydney, Australia

\footnotetext{
*Corresponding author: b-bruecher@gmx.de
} 
B.L.D.M. Brücher et al.: 4open 2020, 3, 1

\begin{abstract}
Based on high quality surgery and scientific data, scientists and surgeons are committed to protecting patients as well as healthcare staff and hereby provide this Guidance to address the special issues circumstances related to the exponential spread of the Coronavirus disease 2019 (COVID-19) during this pandemic. As a basis, the authors used the British Intercollegiate General Surgery Guidance as well as recommendations from the USA, Asia, and Italy. The aim is to take responsibility and to provide guidance for surgery during the COVID-19 crisis in a simplified way addressing the practice of surgery, healthcare staff and patient safety and care. It is the responsibility of scientists and the surgical team to specify what is needed for the protection of patients and the affiliated healthcare team. During crises, such as the COVID-19 pandemic, the responsibility and duty to provide the necessary resources such as filters, Personal Protective Equipment (PPE) consisting of gloves, fluid resistant (Type IIR) surgical face masks (FRSM), filtering face pieces, class 3 (FFP3 masks), face shields and gowns (plastic ponchos), is typically left up to the hospital administration and government. Various scientists and clinicians from disparate specialties provided a Pandemic Surgery Guidance for surgical procedures by distinct surgical disciplines such as numerous cancer surgery disciplines, cardiothoracic surgery, ENT, eye, dermatology, emergency, endocrine surgery, general surgery, gynecology, neurosurgery, orthopedics, pediatric surgery, reconstructive and plastic surgery, surgical critical care, transplantation surgery, trauma surgery and urology, performing different surgeries, as well as laparoscopy, thoracoscopy and endoscopy. Any suggestions and corrections from colleagues will be very welcome as we are all involved and locked in a rapidly evolving process on increasing COVID-19 knowledge.
\end{abstract}

Keywords: Anesthesia, Cancer, Cardiothoracic surgery, China, Coronavirus, COVID-19, Dermatology, Elective surgery, Emergency, Endocrine surgery, Endoscopy, ENT, Epidemic, Epidemiology, Europe, Face masks, General surgery, Germany, Guidance, Gynecology, Inflammation, Italy, Laparoscopy, Laparotomy, Morbidity, Mortality, N95 masks, Neurosurgery, Orthopedics, Pandemic, Patient safety, Pediatric surgery, Pneumonia, Protection, Reconstructive and plastic surgery, Surgical critical care, Respiratory masks, SARSCoV-2, Sepsis, Surgery, Thoracoscopy, Transplantation surgery, Trauma surgery, Urology, Virus

\section{Introduction}

On January 30, 2020 the World Health Organization (WHO) stated on its Situation Report - 10 that "the Emergency Committee on the novel coronavirus (2019-nCoV) under the International Health Regulations (IHR 2005) is meeting today to discuss whether the outbreak constitutes a public health emergency of international concern" [1] and stated on March 11, 2020 in its Situation Report 51 , that "...the assessment that the Coronavirus disease 2019 (COVID-19) can be characterized as a pandemic" [2].

COVID-19 is caused by a single-stranded ribonucleic acid (ssRNA) virus associated with severe acute respiratory syndrome corona virus 2 (SARS-CoV-2) which was first detected in Wuhan, Hubei province in China in December 2019 [3]. COVID-19 is a clade within the subgenus Sarbecovirus, Orthocoronavirinae subfamily, but differs from two other strains, the Middle East respiratory syndrome coronavirus (MERS-CoV) and the severe acute respiratory syndrome coronavirus (SARS-CoV), and is suggested to have originated in bats and/or pangolins $[4,5]$.

Before the outbreak, SARS-CoV-2 circulated among individuals for several weeks and one way it likely entered Europe was through an unrecognized infection by a traveler from Singapore to France on January 24, 2020 where some 21 people were exposed at a ski resort [6]. Coronavirus transmission occurs by physical contact, and through the inhalation or mucous membrane absorption of airborne droplets from infected individuals $[7,8]$ and contrary to assumptions, SARS-CoV-2 has shown no weakening in warm and humid conditions to date [9]. After entering the host, the SARS$\mathrm{CoV}-2$ genome is transcribed and translated with common cold-like symptoms after an incubation time of 2-14 days with a mean incubation period of 5.2 days $(95 \%$ confidence interval [CI]: 4.1-7.0) [3]. The wide spectrum of reported symptoms includes fever, cough, myalgia and fatigue with the most common serious manifestation being pneumonia.

Less common symptoms are headache, sputum production, diarrhea, malaise, shortness of breath/dyspnea and respiratory distress and even anosmia, hyposmia, and dysgeusia [10] explain why its impact in COVID-19 patients from the ENT perspective was raised [11]. Importantly anosmia (loss of smell) as a symptom of COVID-19 infection in the absence of other symptoms was reported which is of significance, as "those patients do not meet current criteria for testing or self-isolation" [12].

In terms of severity, some $81 \%$ are mild (e.g., no or mild pneumonia), $14 \%$ have been reported as being severe (dyspnea, respiratory frequency $\geq 30 / \mathrm{min}$, blood oxygen saturation $\leq 93 \%$, partial pressure of arterial oxygen to fraction of inspired oxygen ratio $<300$, and/or lung infiltrates $>50 \%$ within $24-48 \mathrm{~h}$ ) and $5 \%$ have been noted to be critical (respiratory failure, septic shock, and/or multiple organ dysfunction or failure) with an overall case-fatality rate (CFR) of $2.3 \%$ [13]. It is important to note that patients between the ages of 70-79 years have an 8.0\% CFR and cases 80 years and older have a $14.8 \%$ CFR with $49 \%$ of critical cases reporting a fatal outcome. Taken together, some $80 \%$ of infections will be mild, and $20 \%$ will be moderate or seriously ill. 


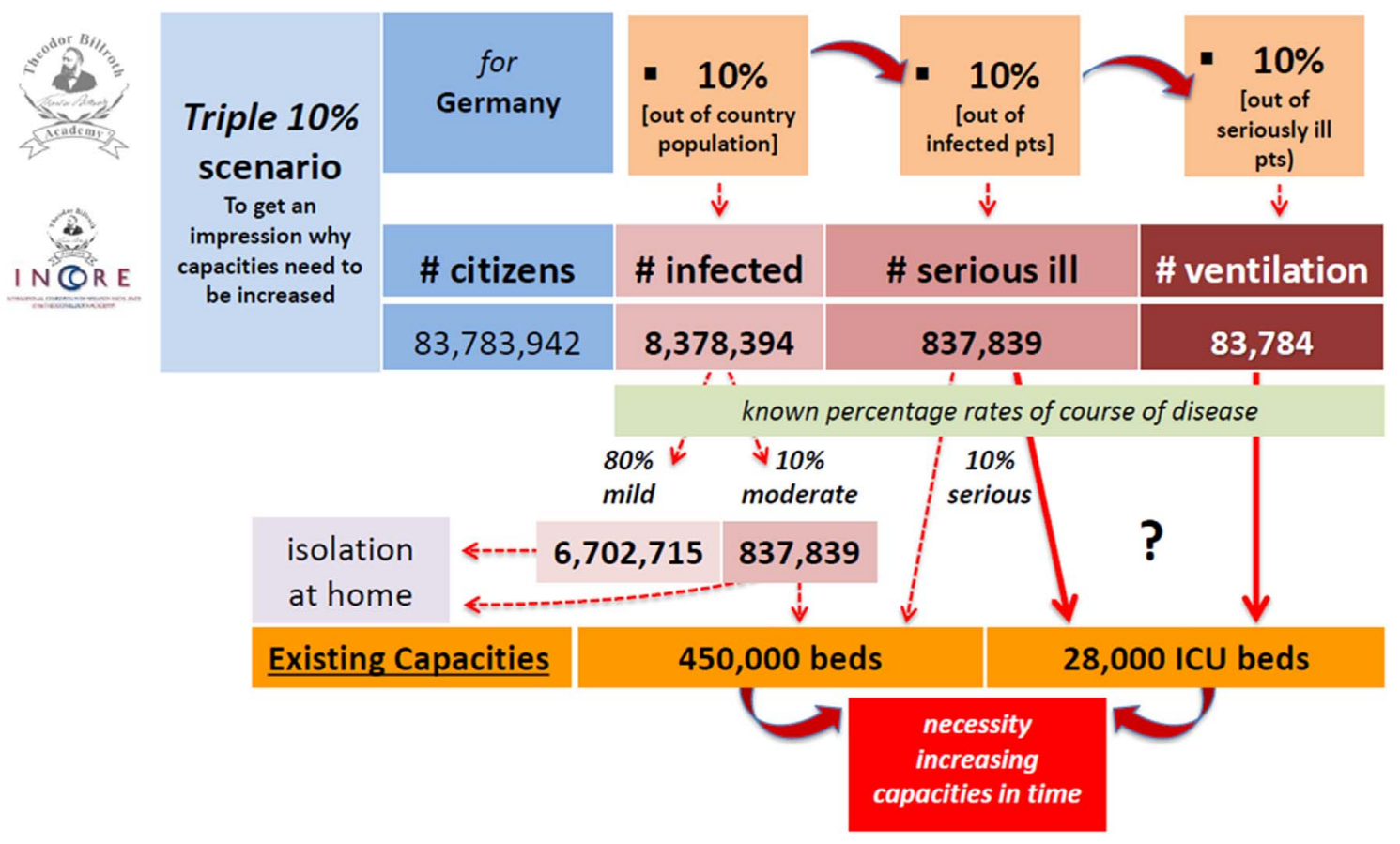

Figure 1. Calculated assumption of a triple $10 \%$ scenario for Germany with 83,783,942 citizens, which has 450,000 hospital beds and 28,000 intensive care unit (ICU) beds although it is a likely underestimation of reality. This figure reveals the necessity of increasing hospital capacities urgently needed during COVID-19 pandemic. Citizen numbers in accordance to Worldometers Website [14]. (Access at March 19, 2020).

These data have made clear that such an outbreak with an exponential increase of infected patients can rapidly overwhelm any healthcare system. To understand why hospital capacities need to be increased rapidly, an assumption of a triple $10 \%$ scenario (a likely underestimation of the reality but provided here as an illustration) calculation for Germany with 83,783,942 citizens, which has 450,000 hospital beds and 28,000 intensive care unit (ICU) beds shows that hospital capacities will urgently need to be increased (Fig. 1, Data retrieved from [14]).

A detailed, complete comprehensive and robust infection workflow for a COVID-19 case had been proposed most recently $[15,16]$. Otherwise practical guidance was missing, until our British colleagues provided on March 26, 2020 the Intercollegiate General Surgery Guidance on COVID-19 and updated it on March 27, 2020 (Fig. 2) [17].

The following recommendations serve as Pandemic Surgery Guidance during the current exponential spread of the COVID-19 throughout the world (Fig. 3).

The objective is to take responsibility to provide guidance for surgery in the COVID-19 crisis in a more practical way addressing practice, healthcare staff and patient safety. As scientists and surgical teams decide what is needed for the protection of patients and staff during such a pandemic, the hospital administration together with the government have the obligation to provide the necessary supplies such as filters, Personal Protective Equipment (PPE) consisting of gloves, fluid resistant (Type IIR) surgical face masks (FRSM), filtering face pieces (FFPs), class 3 (FFP3 masks), face shields, and gowns (plastic ponchos). The suggested
Guidance is a simplified way to address decision-making for our colleagues and staff performing surgery, for the healthcare team and to ensure patient safety and care (Fig. 3).

Suggestions and corrections from colleagues will be welcome as we are all involved in a dynamically developing process on increasing our collective COVID-19 knowledge. Therefore, the proposed recommended steps are listed followed by the rationale for each component of the Guidance.

\section{Considerations}

\section{(1) Emergency Surgery}

$\rightarrow$ COVID-19-testing and risk assessment.

$\rightarrow$ Pneumonia assessment by plain chest X-ray versus 3 quadrant ultrasound versus thoracic CT.

$\rightarrow$ Every surgery entails higher patient and staff risk.

\section{Rationale}

\subsection{COVID-19-testing and risk assessment}

Each patient should undergo COVID-19-testing including a health risk assessment. The European Centre for Disease Prevention and Control (ECDC) defined discharge criteria [18]. In Accordance to the Ministero della salute, Consiglio Superiore di Sanità, Italy (February 28, 2020), "a COVID19 patient can be considered cured after the resolution of 


\section{Intercollegiate General Surgery Guidance on COVID-19}

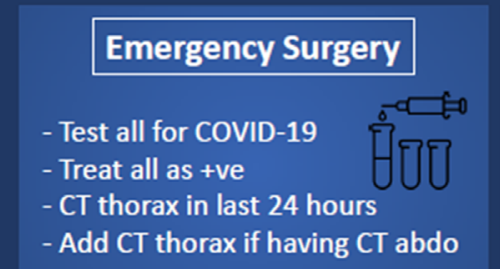

$\triangle$

\section{Theatre}

- Minimum staffing levels

All staff PPE including visors

- Stop +ve pressure ventilation

- Smoke extraction

- Intubation / extubation in theatre

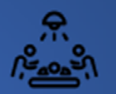

\section{Planned Surgery}

- Risk assessment for COVID-19

Greater risks of surgery

Consent

- Risk-reducing strategies (e.g. stoma)

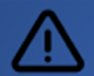

\section{Laparoscopy}

Generally should not be used

- Filters etc. difficult to implement

Appendicitis: open / conserv.

- Cholecystitis: conserv. /

cholecystostomy
PPE

PPE for all laparotomies - Unless COVID-19 negative (beware false negative)

- Include eye protection

- Practise donning \& doffing

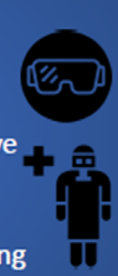

\section{AUGIS 变}

Full guidelines available:

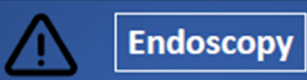

Emergency only

Follow guidance from BSG Upper GI endoscopy requires full PPE
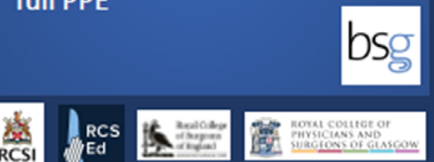

Figure 2. Intercollegiate general surgery guidance on COVID-19 [17].

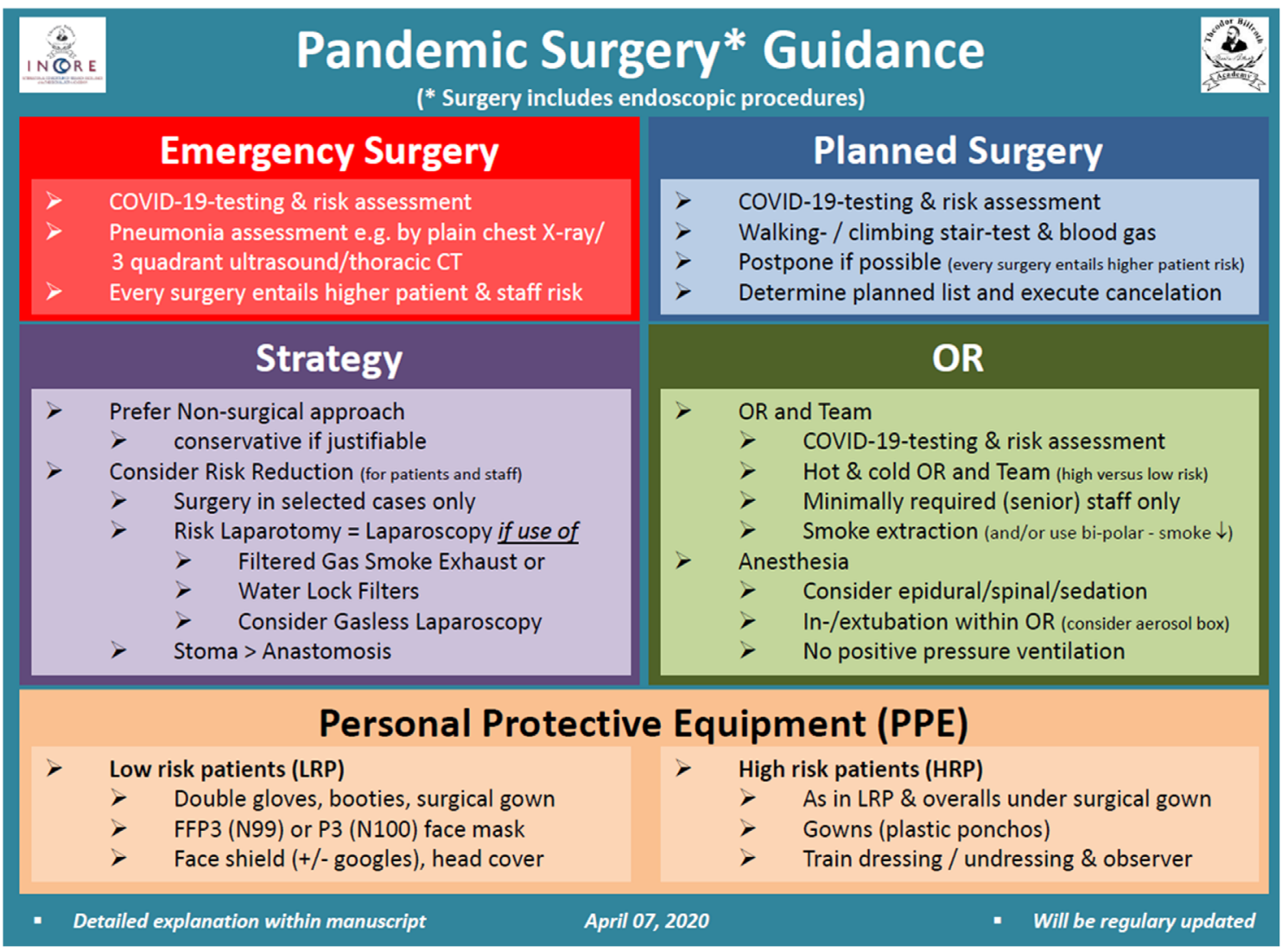

Figure 3. Pandemic Surgery* Guidance. ${ }^{*}$ Surgery includes surgical procedures by distinct surgical disciplines such as numerous cancer surgery disciplines, cardiothoracic surgery, ENT, eye, dermatology, emergency, endocrine surgery, general surgery, gynecology, neurosurgery, orthopedics, pediatric surgery, reconstructive and plastic surgery, surgical critical care, transplantation surgery, trauma surgery and urology, performing different surgeries, as well as laparoscopy, thoracoscopy and endoscopy. 
symptoms and 2 negative tests for SARS-CoV-2 at 24-hour intervals". In China, patients considered to be discharged, need to meet the following criteria: afebrile for $>3$ days, Improved respiratory symptoms, pulmonary imaging shows obvious absorption of inflammation, and nucleic acid tests negative for respiratory tract pathogen twice consecutively (sampling interval $\geq 24 \mathrm{~h}$ ). Currently, the recommendation is improved clinical signs plus two 2 negative tests for SARS-CoV-2.

Nucleic acid amplification tests (NAAT), such as realtime polymerase chain reaction (RT-PCR) are mandatory. Information about specimen collection and procedures are available from the WHO [19]. At present, RT-PCR is the gold-standard performed on nasopharyngeal and/or throat specimens in accordance to the Centers of Disease Control (CDC) with a high specificity (low/no rate of false positive findings) but with a low sensitivity ([20, 21] reviewed in [22]). There is a dynamic process of development of new serological assays and their approval by the regulatory agencies.

A recent study showed that negative SARS-CoV-2 nasopharyngeal testing does not mean that the individual is not infected as 8 out of 10 children with negative nasopharyngeal testing revealed persistently positive rectal swabs testing suggesting the possibility of fecal-oral transmission [23]. This is concordant with the most recent findings that COVID-19 was measured in sewage 3 weeks before the first case was reported in the Netherlands [24].

Despite the need for clinicians to be aware of false negative tests, and although RT-PCR is the gold-standard, rapid tests may be considered such as IgG/IgM antibody lateral flow assay or nCoV-19 Antigen in NP swabs. In Wuhan, China, "throat-swab specimens were obtained for SARSCoV-2 PCR re-examination every other day after clinical remission of symptoms, including fever, cough, and dyspnea, but only qualitative data were available" [25].

The WHO released early guidance for laboratory screening $[19,26]$. Because it takes $5-10$ days to make IgM antibodies (and $\operatorname{Ig} \mathrm{G}$ antibodies develop later), there will be a high false negative rate for $\operatorname{Ig} \mathrm{G} / \mathrm{IgM}$ tests among those tested early without symptoms. Around day 10 after symptom onset, IgG and IgM antibodies increased with seroconversion within 3 weeks [27].

The ECDC released on March 25, 2020 the 7th update of a rapid risk assessment [28]. However, this document describes the dynamics of the COVID-19 pandemic in Europe as rapid information but does not provide a risk assessment for practical use. Health care employees need a risk assessment for patient triage. To meet these needs, various hospitals individually have developed a risk assessment to try to stratify the decision-making process of where each patient should be triaged.

Recently the date providing endpoints, such as of admission to intensive care units, or invasive ventilation, or death from 1590 laboratory-confirmed hospitalized patients in 575 hospitals in 31 province/autonomous regions/provincial municipalities across mainland China between December 11, 2019 and January 31, 2020 were analyzed [29]. After adjusting for age and smoking status, the following comorbidities with their hazard ratio (HR) and $95 \%$ CIs were determined:

- COPD (HR: 2.681, 95\% CI: 1.424-5.048);

- Diabetes mellitus (HR: 1.59, 95\% CI: 1.03-2.45);

- Hypertension (HR: 1.58, 95\% CI: 1.07-2.32); and

- Malignancy (HR: 3.50, 95\% CI: 1.60-7.64).

Patients were further stratified in accordance with composite endpoints in terms of numbers of comorbidities as a greater number of comorbidities correlated with poorer clinical outcomes:

- 1 comorbidity (HR: 1.79, 95\% CI: 1.16-2.77);

- $\geq 2$ comorbidities (HR: 2.59, 95\% CI: 1.61-4.17).

Clinically it is urgently necessary to stratify COVID-19 patients before admission and/or any surgical procedures during the COVID-19 pandemic.

Laboratory tests in COVID-19 patients often show a decrease of platelets and lymphocytes with increases of lactate dehydrogenase $(\mathrm{LDH})$, troponin, C-reactive protein (CRP), D-dimer, serum ferritin, and interleukin 6 (IL-6) [25]. A recommendation using a specimen collection kit with instructions has been developed and is in accordance to the provided CDC criteria [30].

\subsection{Pneumonia assessment e.g. by plain chest $X$-ray/3 quadrant ultrasound/thoracic $C T$}

Early COVID-19 infection and effects on the lungs are crucial in this pandemic, as the disease dynamics in many reported patients can occur within a couple of days resulting in increased mortality. Pneumonia assessment can be done alongside clinical investigation and auscultation e.g., by plain chest X-ray, 3 quadrant ultrasound, and thoracic computed tomography (CT). Although controversial, chest CT should be considered and where indicated, an abdominal CT or an additional chest CT scan should be taken into consideration as well.

Chest CT might contribute as an early diagnostic and monitoring tool for COVID-19 pneumonia. Patients with chest CT scans and signs of pneumonia could be quarantined while waiting for RT-PCR test results but it needs to be taken into account that chest CT in COVID-19 patients reveals a high specificity between 93 and $100 \%$ but a moderate sensitivity of between 72 and 94\% [31]. Additionally, chest CTs might help to stratify patients especially in the absence of rapid access of COVID-19 testing, although a negative chest CT might not exclude COVID-19 infections [32].

Some have argued that the chest CT should not be part of COVID-19 diagnostic criteria [33-37], while others favor CT scans [38-43]. One major argument for performing a CT chest scan is the fact that pneumonia was radiologically diagnosed in some $67 \%$ of COVID-19 negative cases and in 94\% of COVID-19 positive patients [44]. In Hubei, China, CT findings were included as evidence of clinical diagnosis of COVID-19 patients [45] while this recommendation was 
removed in the sixth published version [46]. Even the rates of RT-PCR confirmed COVID-19 infections and synchronous normal CT-findings vary greatly between $2 \%[47,48]$ and $56 \%$ [49].

\subsection{Every surgery entails higher patient and staff risk}

In general, every kind of surgery (including endoscopies and minimally invasive surgery, such as laparoscopy, thoracoscopy) is seen as entailing higher risks.

\section{(2) Planned Surgery}

$\rightarrow$ COVID-19-testing and risk assessment.

$\rightarrow$ Walking/climbing stair-test \& blood gas.

$\rightarrow$ Postpone if possible (every surgery entails higher patient risk).

$\rightarrow$ Determine planned list and execute cancelation.

\section{Rationale}

\subsection{COVID-19-testing and risk assessment (see 1.1)}

\subsection{Walking/climbing stair-test and blood gas}

Easy, inexpensive, and almost forgotten approaches consist of walking/climbing stair-test and blood gas analysis. For example, the 2 stairs climbing capacity with post-test $\mathrm{pO}_{2}>91 \%$ has peri-operative prognostic importance [50].

\subsection{Postpone if possible (every surgery entails higher patient risk)}

The President of the Robert-Koch-Institute (RKI) suggested postponing all elective surgical procedures and interventions in an interview on February 28, 2020 [51]. Furthermore, surgery in general is seen at higher risk for transmission of respiratory infections and especially potentially inducing fatal patient outcome in cases where a COVID-19 diagnosis is overlooked and/or diagnosed later [52]. Therefore, surgery is a high-risk venture for COVID-19 patients.

In Germany, hospitals acted early to increased risk posed by COVID-19 risk, followed by the German Government. On Thursday March 12, 2020 the German Government decided that all justifiable elective admissions, surgical procedures and interventions should be postponed to increase expected capacities in terms of patient beds, intensive care unit (ICU) beds and ventilators [53]. Hospitals were advised to postpone elective surgeries as COVID-19 capacities were judged to be increased nationwide immediately and surgical care should be limited to life-threatening diseases to minimize unnecessary resources in manpower, patient beds and ICU beds, ventilators, antiseptic foaming and use of PPE.

Tufts Medical Center in Massachusetts canceled all planned (elective) surgery early in 2020 calendar week 2, which was followed by the US Surgeon General Jerome Adams' advice on March 14, 2020 via Twitter [54]. The
Centers for Medicare and Medicaid Services (CMS) released on March 18, 2020 a tiered framework as potential help for hospitals and health systems to evaluate suspected COVID-19 needs [55]. On March 19, 2020, the CMS together with the CDC recommended postponing elective surgery in a press release [56]. The United Kingdom reacted on March 17, 2020 [57].

Citing evolving evidence from China, Italy and Iran that otolaryngologists were among the highest risk group of contracting the virus while performing upper airway procedures and examinations, the American Academy of Otolaryngology Head and Neck Surgery AAO-HNS) issued a policy statement limiting care to time-sensitive and emergent problems and the routine use of appropriate $\mathrm{PPE}$ when treating patients in all age groups [58].

\subsection{Determine planned list and execute cancelation}

Complex surgery which itself is associated with higher morbidity and mortality should be deferred [59]. The ACS has provided guidelines for triage to potentially determine planned lists of those procedures which can be canceled [60]. This decision is a clinical one depending on the patient, hospital infrastructure and actual local COVID-19 burden.

\section{(3) Strategy}

$\rightarrow$ Prefer Non-surgical approach

$\rightarrow$ conservative if justifiable

$\rightarrow$ Consider Risk Reduction (for patients and staff)

$\rightarrow$ Surgery in selected cases only

$\rightarrow$ Risk Laparotomy = Laparoscopy if use of

$\rightarrow$ Filtered Gas Smoke Exhaust or

$\rightarrow$ Water Lock Filters

$\rightarrow$ Consider Gasless Laparoscopy

$\rightarrow$ Stoma $>$ Anastomosis

\section{Rationale}

3.1 Prefer Non-surgical approach

(conservative if justifiable)

COVID-19 pneumonia carries a high mortality rate especially during peri- and post-operative times, which is why any kind of surgical treatment should be scrutinized very carefully and postponed if possible. Therefore, preoperative check-up is of importance in terms of patient history (contact within the last 14 days with suspected/confirmed infected cases).

The Australian and New Zealand Hepatic, Pancreatic and Biliary Association (ANZHPBA) provided three surgical COVID-19 response phases into (Phase I) Semi-Urgent Setting (Preparation Phase) (few COVID-19 patients, hospital resources not exhausted, institution still has ICU ventilator capacity and COVID-19 trajectory not in rapid escalation phase), (Phase II) Urgent Setting (many COVID-19 patients, ICU and ventilator capacity limited, operating room supplies limited) and (Phase III) 
"Wartime" footing (Hospital resources are all routed to COVID-19 patients, no ventilator or ICU capacity, operating room supplies exhausted; only patients in whom death is likely within hours if surgery is deferred) [61]. Within this, a complex triage scenario is provided including categorization of hepato-biliary surgical procedures.

Otherwise, emergency patients may be subdivided surgically in an easy way into: (1) urgent surgery required (no time delay allowed), (2) emergency operation required and (3) observation.

Various scoring systems and/or calculators are available for stratification of pre-hospital health status and comorbidities, physiology and outcome risk which often had not been explicitly validated [62]:

$\rightarrow$ American Society of Anesthesiologists Physical Status Grading (ASA-PS) [63];

$\rightarrow$ Charlson Comorbidity Index (CCI) [64];

$\rightarrow$ Physiological and Operative Severity Score for the Enumeration of Mortality and Morbidity (POSSUM) [65];

$\rightarrow$ Surgical Risk Scale (SRS) [66];

$\rightarrow$ Surgical Mortality Score (SMS) [67];

$\rightarrow$ Surgical Risk Score [68];

$\rightarrow$ Physiological Emergency Surgery Acuity Score (PESAS) [69];

$\rightarrow$ Surgical Apgar Score (SAS) [70];

$\rightarrow$ Perioperative Mortality Risk Score (PMRS) [71];

$\rightarrow$ American College of Surgeons National Surgical Quality Improvement Programme (ACS-NSQIP) universal surgical risk calculator [72];

$\rightarrow$ Surgical Outcome Risk Tool (SORT) [73]; , and

$\rightarrow$ Emergency Surgery Acuity Score (ESAS) [74].

Although there is no Level 1 evidence, surgery in potential COVID-19 patients is seen as a high-risk venture which is why recommendations from various international societies favor a non-surgical approach, if justifiable. Nonoperative conservative treatment for example includes cholecystotomy and drainage for acute cholecystitis, insertion of percutaneous transhepatic cholangiography drainage (PTCD) in cholangitis, interventional embolization of acute gastrointestinal bleeding, antibiotic treatment for appendicitis, or even hernia reduction under sedation for incarcerated hernia.

\subsection{Consider Risk Reduction (for patients and staff)}

\subsubsection{Surgery in selected cases only}

The general recommendation is to select surgical cases to minimize the surgical trauma as much as possible independent of the size of incision for ports in laparoscopy or laparotomy.

\subsubsection{Risk Laparotomy = Laparoscopy (includes endoscopy and thoracoscopy) "if use of"}

\subsubsection{Filtered Gas Smoke Exhaust or}

\subsubsection{Water Lock Filters}

We review at first the development of how recommendations were created and point out, which knowledge needs to be taken into account, which explains why the stated risk of laparotomy compared to laparoscopy needs to be seen in a much more differentiated way if available knowledge is addressed and some conditions are considered.

At first, surgeons in Wuhan, China recommended highly selecting laparoscopy [75]; subsequently laparotomy was judged to be more favorable than laparoscopy due to the following arguments put forward by various societies:

- The surgical smoke during laparoscopy using electrical or ultrasonic equipment for 10 minutes results in a significantly higher particle concentration within the smoke compared to laparotomy ([76] reviewed in [77]) although it is possibly the result of the smoke concentrating in a closed space in contrast to smoke that is emitted continuously during laparotomy.

- The standard "surgical masks alone do not provide adequate protection from surgical smoke" [78].

- More than 600 compounds and gases or more can be identified in surgical smoke $[79,80]$.

- This includes viruses such as human immunodeficiency virus (HIV), human papillomavirus (HPV), bovine papillomavirus (BPV) and hepatitis $\mathrm{B}$ virus (HBV) [76, 81-89].

- "Human papillomavirus (HPV) types ... seem to have a predilection for infecting the upper airway mucosa, and laser plume containing these viruses may represent more of a hazard to the surgeon" [83]. Recurrent respiratory papillomatosis (RRP) is caused by HPVtype 6 (HPV-6) and HPV-type 11 (HPV-11) and associated with exophytic lesions of the airway that are friable and bleed easily [90].

- "Swabs from 110 patients in nine separate treatment sessions as well as from five pre-filter canisters, four fume vacuum tubes, and from the nasopharynx, eyelids, and ears of the laser surgeon before and after laser surgery" revealed in up to $60 \%$ papillomavirus DNA to be identified in swabs and even in one of five pre-filter canisters where HPV DNA was positive [81].

- In a recent study, the "concentration number of 0.3 $\mu m$ and $0.5 \mu m$ particles reached the maximum after 10 min of electrosurgical treatment; however, the concentration number of $5 \mu \mathrm{m}$ particles began to decrease after 5-15 min of the treatment" plus "the cumulative particle numbers of $0.3 \mu \mathrm{m}$ and $0.5 \mu \mathrm{m}$ in laparoscopic operation were higher than those of laparotomy after 10 min of the treatment" suggesting that "surgical smoke prevention should use smoke evacuator" and that "health-care workers should also wear a highly efficient tight seal-fit mask in the OR" to avoid risk and damage [76].

The Royal College of Surgeons of England (RCS), Royal College of Physicians and Surgeons of Glasgow, the Royal College of Surgeons of Edinburgh and the Royal College of Surgeons of Ireland released guidance for surgeons on March 20, 2020 [91]. The American College of Surgeons (ACS) released elective case triage guidelines for surgical care on March 24, 2020 [60]. Afterwards an intercollegiate general surgery guidance arrived on March 26, 2020 which was updated on March 27, 2020 (Fig. 2) [17]. 


\section{SAGES and EAES Recommendations: Surgical Response to COVID-19}

Personal Protection

Minimum number of theatre staff

All staff wear PPE

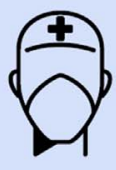

Service Rationalization

Postpone all elective cases

Minimize face to face consultation

Virtual MDT meetings

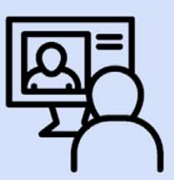

Laparoscopy

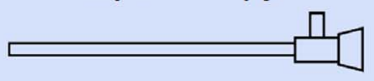

Little evidence of MIS risk specific to COVID-19

Proven benefits of reduced length of stay and fewer complications

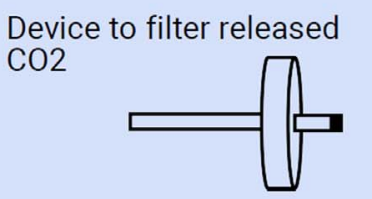

Minimize use of energy devices

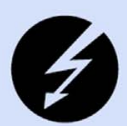

\section{Practical Measures}

Consent covers risk of COVID-19

All patients tested prior to surgery, if possible

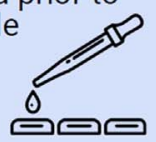

Dedicated OR for COVID-19

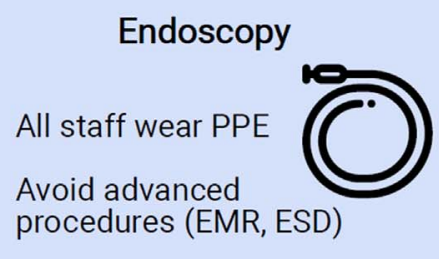

Full guidelines available at www.sages.org or www.eaes.eu

Figure 4. Society of American Gastrointestinal and Endoscopic Surgeons (SAGES) and the European Association for Endoscopic Surgery (EAES) recommendations regarding surgical response to COVID-19 crisis [93].

The recommendations of British and US societies had been reviewed [17, 55-57, 60, 91]. Therefore, it had been assumed that laparotomy was favored over laparoscopy, and laparoscopy, thoracoscopy, and endoscopy should be performed on selected cases only and that although COVID-19 data in terms of surgical smoke are still missing, protection of viral transmission by surgical smoke would need to be addressed through the use of PPE based on earlier evidence.

Following publication of these guidelines, surgical societies around the world expressed disagreement with the recommendation to strictly avoid laparoscopy. Although laparoscopic surgery is considered an aerosol generating procedure (AGP), this aerosol together with the $\mathrm{CO}_{2}$ pneumoperitoneum is in a controlled cavity.

In open surgery electrosurgical instruments produce smoke and aerosolization of tissue as much as in laparoscopy; however the dissipation of this material is to the open operating theatre space affecting all staff. Smoke evacuation attached to monopolar devices are helpful but have limited efficacy. Moreover, glove tearing and fluid or blood splashing can cause direct contact with bodily fluids whereas in laparoscopy these are avoided.

The Society of American Gastrointestinal and Endoscopic Surgeons (SAGES) together with the European Association for Endoscopic Surgery (EAES) stated that "either open, laparoscopic or robotic" surgeries need to be taken into account and that "protective measures are strictly employed for OR staff safety and to maintain a functioning workforce" [92].

However, it was pointed out by the SAGES that the evidence in terms of favoring laparotomy over laparoscopy is low ([77] reviewed in [92]).

Another parameter that needs to be considered is the quicker discharge of patients following laparoscopic surgery. In this COVID-19 pandemic, hospital resources are scarce and hospital beds, healthcare personnel and equipment should be saved for critically ill patients rather than standard post-operative care of surgical patients. Laparoscopy allows for faster discharge from hospitals and less dealing with surgical wounds and surgical site infections (SSIs). This is why the two largest world associations dealing with laparoscopy, the Society of American Gastrointestinal and Endoscopic Surgeons (SAGES) and the European Association for Endoscopic Surgery (EAES), quickly released their recommendations regarding surgical response to COVID19 (Fig. 4) [93].

Experience in laparoscopic surgery was published to disseminate knowledge and provide guidelines for minimally invasive surgery procedures. The China and Italy experiences are particularly helpful by providing suggestions like using low pressure peritoneum, use of balloon trocars, evacuating all pneumoperitoneum before trocar removal or specimen extractions [77]. 


\section{Remark}

Knowledge which needs to addressed

Screening 3363 individuals enrolling 246 individuals with exhaled breath samples explored the value of respiratory droplets and aerosol routes of transmission with a particular focus on coronaviruses, influenza viruses, and rhinoviruses and showed that surgical face masks significantly reduced detection of influenza virus RNA in respiratory droplets and coronavirus RNA in aerosols, with a trend toward reduced detection of coronavirus RNA in respiratory droplets [94].

The importance of the appropriate smoke extraction equipment had been pointed out earlier [95]. Although cell particles had been found in the smoke plume, until now the risk to the OR staff is still not defined [96] and the hazards in terms of tumor cells in the surgical smoke from tumor dissection by ultrasonic scalpel are unclear at present [88].

Mintz et al. together with the Technology Committee of the EAES pointed out that "Standard electrostatic filters used for ventilation machines have the capability of filtering known bacterial and viral loads with great efficiency and most are certified for $99.99 \%$ effective protection against $\mathrm{HBV}$ and $\mathrm{HCV}$ which have a diameter of 42nm and 30-60 $n m$ respectively" and that "SARS-CoV-2 has a larger diameter of 70-90 $\mathrm{nm}$ " which is why "the same filtering efficiency can be expected to apply for new virus" ([97-99] reviewed in [100]).

Due to this, the capability of evacuating smoke was effectively shown by surgeons in Israel and Italy in five operations without using an active suction system, which was accepted for publication in Annals of Surgery on April 03, 2020 [100]:

$\rightarrow$ Cholecystectomy,

$\rightarrow$ Inguinal hernia repair,

$\rightarrow$ Total Mesorectal Excision (TME),

$\rightarrow$ Transanal Total Mesorectal Excision, and

$\rightarrow$ Anterior resection of the rectum.

Each surgeon reported very good efficiency of the passive smoke evacuation system during laparoscopic procedures and that "the filter system should be discarded according to hospitals protocols for infection control".

The EAES technology committee provided guidance for safe use of laparoscopy, to evacuate gas and smoke from the abdomen through a simple low cost adequate filter, to evacuate smoke and aerosol using standard ventilation machines filtering device and available connecting components to reduce the risk of OR staff infection [100]. This publication even includes two videos, (1) how the system can be assembled with standard OR equipment and (2) the demonstration during a total mesorectal excision procedure. Despite regular instrument cleaning during surgery as well as deflating pneumoperitoneum prior to trocars as previously recommended by colleagues from China and Italy [77], we recommend adding such filters (mentioned above) to the suction system both in laparoscopy and laparotomy
(Fig. 1 in Mintz et al. Ann Surg 2020, not included here) [100].

\subsubsection{Consider Gasless Laparoscopy}

A nearly forgotten approach is performing laparoscopic 0surgery in the old-fashioned way, gasless for acute appendicitis, acute cholecystitis and as a diagnostic tool.

\subsubsection{Stoma $>$ Anastomosis}

The Royal College of Surgeons suggested that "stoma formation rather than anastomosis to reduce the need for unplanned post-operative critical care for complications" be considered [17].

\section{(4) Operation Room (OR)}

$\rightarrow$ OR and Team

$\rightarrow$ COVID-19-testing and risk assessment

$\rightarrow$ Hot and cold OR and Team (high vs. low risk)

$\rightarrow$ Minimally required (senior) staff only

$\rightarrow$ Smoke extraction (and/or use bi-polar - smoke $\downarrow$ )

$\rightarrow$ Anesthesia

$\rightarrow$ Consider epidural/spinal/sedation

$\rightarrow$ In-/extubation within OR (consider aerosol box)

$\rightarrow$ No positive pressure ventilation

\section{$4.1 \mathrm{OR}$ and Team}

\subsubsection{COVID-19-testing \& risk assessment}

The OR team should be tested and undergo a risk assessment. In an evolving scenario it may be possible to select OR staff with proven COVID-19 exposure to man the hot ORs. When serology tests become available all theater staff should undergo serology testing.

\subsubsection{Hot and cold OR and Team (high vs. low risk)}

We recommend to use - if possible - a hot (H-OR) and cold operation room (C-OR) and designating an area to differentiate between operations on confirmed/suspicious COVID19 positive versus negative/non-suspicious patients. As mentioned earlier, we are aware that there are infected patients with negative testing. Within the H-OR area, filtering of ventilation is important and - if possible negative pressure operating rooms should be used. Emergency operations, on which no time delay due to life-threatening condition occurs while to date no rapid COVID-19 test is widely available, should always be operated within the $\mathrm{H}$ $\mathrm{OR}$ area. PPE is required for $\mathrm{H}-\mathrm{OR}$.

\subsubsection{Minimally required (senior) staff only}

In order to avoid any potential risk of infection for the patient and the surgical staff and to minimize further spread of SARS-CoV-2 virus, the personnel required to perform a necessary operation should be kept to a minimum [101]. This strict implementation has several advantages. ORs usually have positive pressure technology in the operating area (aseptic zone) and are separated from other areas 
by doors. But when the doors to the anterooms are opened, the well-directed laminar air flow will be disrupted and thus particles and aerosols within the OR air can be swirled which provides an explanation why it should be considered to not apply a positive pressure ventilation in the OR under this specific COVID-19 situation.

Recently, it was even recommended to set up a negative pressure in the operating theatre to reduce virus dissemination beyond the OR [102]. Such an approach is recommended since a long time, but the direction of airflow in respiratory isolation rooms is often not correct [103] and should be evaluated.

Nevertheless, air-turbulences are worse the more people are in the OR with or without negative air ventilation. Small expert teams of lead surgeons $(N=2)$, mechanical devices to provide for optimal exposure, most experienced surgical assistants ( $N=2$; one instrumentalist, one in-room OR nurse) and anesthesiologist with one anesthesia nurse $(N=2)$ act as a well-coordinated team, another reason to minimize human movements within the aseptic zone. The team should perform a huddle before surgery to talk through the surgical and anesthesiological process and associated risks and perform a time out at the end of surgery to discuss postoperative risks and consequences as well as quality of the COVID-19 risk management.

Hospital transmission was reported being responsible for some $41 \%$ nosocomial SARS infections [15]. Even postponing and/or suspending postoperative visits were reported in Singapore to minimize exposure and spread [102].

Protecting OR staff includes "surgeons, anesthetists, and nurses and all possible transiting persons in the OR" [77]. Limiting medical staff in the OR results in decreased exposure and spread of COVID-19 with increased protection of health care teams. Only senior experienced staff and not trainees or students should be involved in surgical cases during this pandemic [52]. In some academic centers, pathology service is included into the OR tract. We recommend suspending this kind of pathology service during the current outbreak.

\subsubsection{Smoke extraction (and/or use bi-polar - smoke $\downarrow$ )}

Major content has been reviewed in detail above (see 3. Rationale). Any form of electrosurgery produces smoke, which should be minimized as much as possible decreasing potential aerosolization and consecutive harming the patient and/or OR staff. If available, bi-polar diathermy including smoke suction/evacuators should be used.

The argument of the necessity of smoke extraction and/ or use of bi-polar tools which produce less smoke derives from the evidence reviewed in the rationale for point (3). Due to the high viral load in asymptomatic patients which is comparable to symptomatic patients, and was implicated that the very early transmission during the COVID-19 course differs significantly in terms of strict regulations compared to the earlier SARS-CoV epidemic between 2002 and 2003 [104].

Screening 3363 individuals enrolling 246 individuals with exhaled breath samples explored the value of respiratory droplet and aerosol routes of transmission with a particular focus on coronaviruses, influenza viruses and rhinoviruses showed that surgical face masks significantly reduced detection of influenza virus RNA in respiratory droplets and coronavirus RNA in aerosols, with a trend toward reduced detection of coronavirus RNA in respiratory droplets [105].

Furthermore, any airway procedures are now seen as enhancing risk to the performer: intubation and ventilation by anesthetists, and surgical procedures (including various procedures by distinct surgical disciplines such as numerous cancer surgery disciplines, cardiothoracic surgery, ENT, eye, dermatology, emergency, endocrine surgery, general surgery, gynecology, neurosurgery, orthopedics, pediatric surgery, reconstructive and plastic surgery, surgical critical care, transplantation surgery, trauma surgery and urology, performing different surgeries, as well as laparoscopy, thoracoscopy and endoscopy) and this is why protection is mandatory. Various specialties and especially ear nose throat (ENT) surgeons are at high risk. The various specific roles and responsibilities of all OR team members have been reviewed by the ACS including the in- and extubation within the operating room [106].

\subsection{Anaesthesia}

\subsubsection{Consider epidural/spinal/sedation}

Epidural combined spinal-epidural anesthesia was shown to be safe for Cesarean delivery in parturients with COVID19 , although the incidence of hypotension appeared excessive [107]. This approach should certainly be used for incision and drainage of large abscesses, strangulated femoral and inguinal hernia with low risk of bowel ischemia. Inadequate sedation may result in high risk during intubation in case the patient gets agitated and/or has a coughing attack with further risk of pathogen transmission.

\subsubsection{Intubation and extubation within $O R$ (consider aerosol box)}

"Bag valve-mask ventilation, non-invasive ventilation, and intubation (in spontaneously breathing patients), may create localized aerosol generation that can allow airborne transmission to those closely involved in the procedure" ([108] reviewed in [109]). Extubation is associated with increased coughing [110]. To minimize risks to health care providers, in- and extubation should only be done - if possible - within the OR.

An "aerosol box" consisting of a transparent plastic box has been widely adapted for use in various ORs around the world "that effectively shields a provider's face from a patient's airway while allowing the provider to move his/ her arms freely to perform all necessary tasks during endotracheal intubation" [111]. This aerosol box has been developed pro bono by the anesthesiologist Hsien Yung Lai from Mennonite Christian Hospital in Hua Lian, Taiwan, and registered under a Creative Commons license. Lateral ports have been added by Philippine ENT surgeons for tracheostomy and upper aerodigestive tract surgery.

Virological analysis of COVID-19 patients showed high pharyngeal virus shedding during the first week, 
(on day 4: $7.11 \times 108$ RNA copies per throat swab) with confirmation of active viral replication followed by seroconversion after day 7 in up to $50 \%$ of patients (14 days in all) [112]. This even serves as an argument that anaesthetists only should be within the OR during intubation and/or extubation.

\subsubsection{No positive pressure ventilation}

Positive airway pressure (continuous positive airway pressure, CPAP/Bilevel Positive Airway Pressure, BiPAP) is recommended to be avoided in procedures on COVID-19 patients due to the potential risk of pathogen transmission over distances ([113] reviewed in [109]) although safe reports are available ([114] reviewed in [109]).

\section{Personal Protective Equipment (PPE)}

$\rightarrow$ Low risk patients (LRP)

- Double gloves, booties, surgical gown

- FFP3 (N99) or P3 (N100) face mask

- Face shield (+/- googles), head cover

$\rightarrow$ High risk patients (HRP)

- As in LRP plus overalls under surgical gown

- Gowns (plastic ponchos)

- Train dressing/undressing and supervision

In general, any kind of surgical procedure should include wearing low risk PPE and as provided in Figure 3, and high-risk PPE in case of emergency operations (without testing), positively tested patients, and negatively tested patients with a patient history of COVID-19 exposure.

Even non-symptomatic people can spread COVID-19 with high efficiency [115]. To date, there has been confusion about the silent carrier transmission rate. A statistical modeling approach to derive the delay-adjusted asymptomatic proportion of infections estimated a silent carrier rate of $17.9 \%$ [116] but the reality seems to be worse with reported $46.5 \%$ non-symptomatic infected people during the outbreak on the Diamond Princess Cruise ship [117]. This emphasizes the need for urgent aggressive protection approaches to be implemented immediately. "The basic reproduction rate was initially 4 times higher on-board compared to the epicentre in Wuhan, China" and it was estimated, that evacuating all Diamond Princess Passengers and crew early during the outbreak "would have prevented many more passengers and crew from infection" [118].

Based on the outbreak definition in accordance to German Law - transmission of disease of two or more people with a common cause probable or strongly suspected, $\S 6$ IfGS (= Infection Protection Act, In German: Infektionsschutzgesetz) -, the local health department (In German: Gesundheitsamt) ordered a shutdown of a teaching hospital in Germany and put it under quarantine (personal communication). For the first time, all patients plus all employees of one German hospital (physicians, nurses, and health care providers) were tested from Friday April 03 through Sunday April 05, 2020. The teaching hospital's proven COVID-19 patient load on Friday, April 03, 2020 was:
34 patients, of whom 11 on intensive care unit (ICU) (on ventilation), 1 on intermediate care unit (IMC), and 22 on infection ward; another 32 patients on another infection ward were suspicious for COVID-19 with pending test results.

The following information is given anonymously by ercentages only to protect the identity of the hospital in Germany:

A total of 1,162 PCR test were performed, 774 in hospital staff, 260 in patients and in 128 physicians, resulting into $n=19$ COVID-19 positive individuals, resulting into a silent carrier (asymptomatic) rate of $1.6 \%$. Positive tested individuals were isolated and the quarantine lifted.

These experiences underpin the necessity to strictly follow the guidance of the RKI. Furthermore, it reveals, that COVID-19 transmission can be low but it is impossible to prevent in a hospital setting even when the system is not completely overwhelmed with COVID-19 positive patients. Therefore we recommend the testing as provided in Figure 3 out of protection reasons for patients and staff.

SARS-CoV-2 and SARS-CoV are both similar in size (approximately $85 \mathrm{~nm}$ ). Virus particles can penetrate five surgical masks stacked together why it is recommended that health care providers wear N95 (series \# 1860) and not the usual surgical masks [119]. Decreasing the rate of virus particles to as small as $10-80 \mathrm{~nm}$ size by inhalation can be decreased to a $5 \%$ penetration rate simply by using N95 masks (series \#1860) [120]. Protection management must include eye protection (either goggles or full-face shield) as well [121, 122]. During the chaotic phases of COVID-19 spread in Asia and Italy, any kind of eye protection was used, even personal goggles (model 9302-245; Uvex, Germany).

PPE recommendation in treating critically ill COVID19 patients include using double gloves, booties, fluid-resistant surgical gown, FFP3 (N99) or P3 (N100) face masks, and eye protection face shield $(+/-$ googles $)$, and a head cover ([108] reviewed in [22, 109]).

Furthermore, any health care provider above 65 years of age with an increased co-morbidity risk (heart failure, hypertension, lung disease, etc.) is at high risk in being part of the H-OR, unless swab proven exposure to COVID-19 and a minimum 2 weeks isolation, or non-OR presence after last symptoms.

We recommend differentiating low risk patients (LRP) with no history and/or clinical and/or laboratory sign of COVID-19 versus high risk patients (HRP) who have a positive COVID-19 test and/or history of COVID-19 exposure.

In HRP it is mandatory to wear PPE as in LRP patients plus additional gowns such as plastic ponchos. The dressing and undressing should be regularly done under trained supervision, and in real time requires a buddy system to be in place (much like scuba diving).

Based on what we currently know, patients and health care providers are at high-risk for severe COVID-19 illness if 65 years of age or older, are living with home care or are cared for in a long-term facility for the elderly. Furthermore, people of all ages with certain comorbidities are at higher risk for severe illness, particularly if the underlying medical conditions are not well controlled. Chronic lung dis- 
ease or moderate to severe asthma, serious heart conditions, people in immune compromised situation, including cancer treatment, smoking, bone marrow or organ transplantation, immune deficiencies, poorly controlled HIV or acquired immune deficiency syndrome (AIDS), and prolonged use of corticosteroids and other immune weakening medications, severe obesity (body mass index [BMI] of 40 or higher), diabetes mellitus, chronic kidney disease, in need of dialysis, and liver diseases are all such illnesses that have to be taken into account and these patients need PPE from patient admission to the OR, during the operation, and after discharge via recovery room to the ward [22].

\section{Discussion}

Responding to the COVID-19 pandemic, countries around the globe have increased hospital capacities, especially in terms of ICU beds and ventilators. Next to patients, any health care provider needs to be protected as well. It is imperative to functionally sustained healthcare capacity to avoid a worst case scenario: widespread COVID-19 transmission to OR staff increasing individual risk to physicians and nurses and subsequent depletion of essential human resources.

Our comprehensive and robust recommendation serves as Pandemic Surgery Guidance during the exponential spread of the COVID-19 or future similar outbreaks throughout the world (Fig. 3).

Protective procedures in the operation room at Shanghai East Hospital, Tongji University, were provided in an interview with Xiaohu Jiang, MD, PhD, Professor of Surgery [75]. We review them here as each single step has sound practical value:

1. Operations should be done in a negative pressure OR with separate passage. Operation observation is forbidden.

2. Operation sheets should be waterproof.

3. PPE shall be in accordance with level III protection standards.

4. The wearing process of personnel on the operating table (wearing two-layer surgical caps, three-layer sterile gloves, two masks, two pairs of shoe covers, two disposable surgical gowns, one medical protective clothing, one goggles, one protective screen and one boot cover).

- Step 1: Enter the OR, disinfect hands, change protective slippers, and enter the dressing room. Wash hands in seven steps, change personal clothes, wear hand washing clothes, remove personal articles such as jewelry, watches, mobile phones, etc., and wear disposable surgical caps.

- Step 2: Wear medical protective mask and do a tightness test.

- Step 3: Wear goggles, shoe covers and disinfect hands.

- Step 4: Enter the buffer zone after self-inspection. Hand disinfection, inspection of medical protective clothing (model, integrity, etc.), wearing disposable medical protective clothing.
- Step 5: Disinfect hands, wear the first layer of sterile gloves, cover the cuff of protective clothing, and use adhesive tape to fix the cuff if necessary.

- Step 6: Wear disposable surgical cap.

- Step 7: Wear disposable surgical mask.

- Step 8: Wear disposable surgical clothes.

- Step 9: Disinfect the hands, wear the second layer of sterile gloves, and cover the cuff of disposable surgical clothes.

- Step 10: Wear a protective screen.

- Step 11: Wear waterproof boot cover.

- Step 12: Wear outer shoe cover.

- Step 13: Disinfect the hands, confirm the correct donning of clothing with the help of others, check whether all PPE is complete, intact and appropriate in size, ensure that the two layers of medical personnel are tightly protected and the body is not exposed, and enter the operating room after self-inspection in a mirror.

- Step 14: Disinfect surgical hands (disinfect hands and wrists with hand sanitizer, i.e. the scope of the second pair of gloves), and wear disposable sterile surgical clothes.

- Step 15: Wear the third layer of sterile gloves, and cover the cuff of sterile surgical gown.

5. Measures to prevent aerosol transmission.

- The smoke generated by the use of the electrosurgical equipment will form aerosols. During the operation, an aspirator can be used to absorb the smoke, but the suction operation can also cause the generation of aerosols. Therefore, it is recommended to reduce the negative pressure suction operation during the operation, and use the electrosurgical smoking device to reduce the diffusion of aerosols.

- Closed negative pressure suction system shall be used. The disposable negative pressure suction bag shall be added with effective chlorine containing disinfectant of $5000 \mathrm{mg} / \mathrm{L}-10,000 \mathrm{mg} / \mathrm{L}$ before operation, and sealed after operation, and treated as infectious medical waste.

- Endoscopic surgery should be minimized, because there is no evidence to rule out whether the leakage of pneumoperitoneum pressure in endoscopic surgery contributes to aerosol transmission pathways, or whether there is the possibility of increasing the risk of infection of the operating personnel.

\section{Summary}

A consortium of scientists and clinicians from various specialties provided a compact Pandemic Surgery Guidance to serve as more practical guide during the exponential pandemic COVID-19 spread (Fig. 3). The guidance is relevant for surgical procedures by distinct surgical disciplines such as numerous cancer surgery disciplines, cardiothoracic surgery, ENT, eye, dermatology, emergency, endocrine surgery, general surgery, gynecology, neurosurgery, orthopedics, pediatric surgery, reconstructive and plastic surgery, surgical critical care, transplantation surgery, trauma surgery and urology, performing different surgeries, as well 
as laparoscopy, thoracoscopy and endoscopy. The present Pandemic Surgery Guidance could even serve as the basis for other future potential pathogen crises yet to come. Suggestions and corrections from colleagues will be welcomed as we are all involved in a dynamically developing process to increase our collective COVID-19 knowledge.

\section{Nomenclature}

\begin{tabular}{|c|c|}
\hline AAO-HNS & $\begin{array}{l}\text { American Academy of Otolaryngology } \\
\text { Head and Neck Surgery }\end{array}$ \\
\hline $\mathrm{ACS}$ & American College of Surgeons \\
\hline ACS-NSQIP & American College of Surgeons National \\
\hline & $\begin{array}{l}\text { Surgical Quality Improvement Pro- } \\
\text { gramme universal surgical risk calculator }\end{array}$ \\
\hline AIDS & Acquired immune deficiency syndrome \\
\hline ANZHPBA & $\begin{array}{l}\text { Australian and New Zealand Hepatic, } \\
\text { Pancreatic and Biliary Association }\end{array}$ \\
\hline ASA-PS & $\begin{array}{l}\text { American Society of Anesthesiologists } \\
\text { Physical Status Grading }\end{array}$ \\
\hline $\mathrm{BiPAP}$ & Bilevel Positive Airway Pressure \\
\hline BMI & Body mass index \\
\hline $\mathrm{BPV}$ & Bovine papillomavirus \\
\hline CCI & Charlson Comorbidity Index \\
\hline $\mathrm{CDC}$ & Center of Disease Control \\
\hline $\mathrm{C}$ & Case-fatality ra \\
\hline
\end{tabular}

CMS Centers for Medicare \& Medicaid Services C-OR Cold (low risk) operation room (OR)

COVID-19 Coronavirus disease 2019

CPAP Continuous positive airway pressure

CRP C-reactive protein

CT Computed tomography

EAES European Association for Endoscopic Surgery

EASA Emergency Surgery Acuity Score

ECDC European Centre for Disease Prevention and Control

FFP3 Filtering Face Pieces, class 3

FRSM Fluid resistant (Type IIR) surgical face masks

HBV Hepatitis B virus

HIV Human Immunodeficiency Virus

HPV Human papillomavirus

HPV-6 Human papillomavirus type 6

HPV-11 Human papillomavirus type 11

H-OR Hot (high risk) operation room (OR)

HR Hazard ratio

ICU Intensive care unit

IL-6 Interleukin 6

IMC Intermediate care unit

LDH Lactate dehydrogenase

LRP Low risk patients

HRP High risk patients

MERS-CoV Middle East respiratory syndrome coronavirus

NAAT Nucleic acid amplification test

OR
PESAS Physiological Emergency Surgery Acuity Score (PESAS)

PMRS Perioperative Mortality Risk Score

POSSUM Physiological and Operative Severity Score for the Enumeration of Mortality and Morbidity

PPE Personal Protective Equipment

PTCD Percutaneous transhepatic cholangiography drainage

RCS Royal College of Surgeons of England

RKI Robert-Koch-Institute

RT-PCR Real-Time Polymerase Chain Reaction

SAGES Society of American Gastrointestinal and Endoscopic Surgeons

SARS-CoV Severe Acute Respiratory Syndrome Coronavirus

SARS-CoV-2 Severe Acute Respiratory Syndrome Corona Virus 2

SAS Surgical Apgar Score

SMS Surgical Mortality Score

SORT Surgical Outcome Risk Tool

SRS Surgical Risk Scale

WHO World Health Organization

\section{Supplementary material}

Supplementary Material is available at https://www. 4open-sciences.org/10.1051/fopen/2020002/olm

\section{Acknowledgments}

The manuscript was created in very focused and fast way (4 days). By this, we used a new way of a social medium to receive and exchange material fast for review and points of criticism. None of the colleagues was used to it, but anyone who accepted that logistical way made it happen, to review, edit and change content fast $(<24 \mathrm{~h})$. The manuscript was supported by the Theodor-BillrothAcademy ${ }^{\circledR}\left(\mathrm{TBA}^{\circledR}\right)$ and INCORE, (International Consortium of Research Excellence) of the $\left(\mathrm{TBA}^{\circledR}\right)$. We express our gratitude to the discussions on the web group of the Theodor-Billroth-Academy ${ }^{\circledR}\left(\right.$ TBA $\left.^{\circledR}\right)$ on LinkedIn, the exchange with scientists at Researchgate.com, as well as personal exchanges with distinguished colleagues who stimulated our thinking - we thank each one. The authors highly acknowledge the extreme helpful and professional fast peer-review process of the handling Editor as well as of the excellent peer-reviewers.

\section{Dedication}

The authors dedicate the publication to all COVID-19 victims as well as to all physicians, nurses and health care providers who gave everything they had and lost for the benefit of their patients. 


\section{Conflict of Interest}

The author reports the following conflict of interest: Björn LDM Brücher is Editor-in-Chief in Life SciencesMedicine of 4open by EDP Sciences. Ijaz S Jamall, Marjan Slak Rupnik, Ray Perkins and Bruno Zilberstein are Senior Editorial Board members. The following colleagues are Editorial members in Life Sciences-Medicine of 4open by EDP Sciences: Jochen Salber, Avraham Rivkind, Jose Florencio F Lapeña Jr., Rainer Kube, Michael Scherer, Jose da Costa, Rainer Lück, Mesut Tez, Selman Sökmen, Edouard Matevossian, Nelson Elias, Grzegorz Wallner, and Mohammad Kermansaravi. The authors, of their own initiative, suggested publishing the manuscript as a Rapid Publication with online reviewing including to the Managing Editorial to perform a transparent peer-review of their submittals. No author took any action to influence the standard submission and peer-review process, and all report no conflict of interest. The authors alone are responsible for the content and writing of the manuscript. This manuscript contains original material that has not previously been published. The idea for this manuscript came from the first author. After a structure was created, INCORE members, such as Björn LDM Brücher, Ijaz S Jamall, and Marjan Slak Rupnik revised it and the body text was created. Each single author contributed to acquisition and/or analysis and interpretation of data. Every single author read, reviewed and edited the manuscript. All authors contributed to the manuscript and its discussion and summary and approved the final manuscript. Each author agrees to be accountable for all aspects of the work. The Uniformed Services University of the Health Sciences author reported no proprietary or commercial interest in any product mentioned or concept discussed in this article. The opinions or assertions contained herein are the private ones of the author and are not to be construed as official or reflecting the views of the Department of Defense, the Uniformed Services University of the Health Sciences or any other agency of the U.S. Government.

\section{References}

1. World Health Organization (WHO) (2020), Coronavirus disease 2019 (COVID-19) Situation Report - 10. Available from https://www.who.int/docs/default-source/coronaviruse/situation-reports/20200130-sitrep-10-ncov.pdf?sfvrsn= d0b2e480_2. (Accessed March 2020).

2. World Health Organization (WHO) (2020), Coronavirus disease 2019 (COVID-19) Situation Report - 51. Available from https://www.who.int/docs/default-source/coronaviruse/ situation-reports/20200311-sitrep-51-covid-19.pdf?sfvrsn= 1ba62e57_10. (Accessed March 2020).

3. Li Q, Guan X, Wu P, Wang X, Zhou L, Tong Y, Ren R, Leung KSM, Lau EHY, Wong JY, Xing X, Xiang N, Wu Y, Li C, Chen Q, Li D, Liu T, Zhao J, Liu M, Tu W, Chen C, Jin L, Yang R, Wang Q, Zhou S, Wang R, Liu H, Luo Y, Liu Y, Shao G, Li H, Tao Z, Yang Y, Deng Z, Liu B, Ma Z, Zhang Y, Shi G, Lam TTY, Wu JT, Gao GF, Cowling BJ, Yang B, Leung GM, Feng Z (2020), Early transmission dynamics in Wuhan, China, of novel coronavirus-infected pneumonia. N Engl J Med 382, 1199-1207. https://doi.org/ 10.1056/NEJMoa2001316.

4. Lu R, Zhao X, Li J, Niu P, Yang B, Wu H, Wang W, Song H, Huang B, Zhu N, Bi Y, Ma X, Zhan F, Wang L, Hu T, Zhou H, Hu Z, Zhou W, Zhao L, Chen J, Meng Y, Wang J, Lin Y, Yuan J, Xie Z, Ma J, Liu WJ, Wang D, Xu W, Holmes EC, Gao GF, Wu G, Chen W, Shi W, Tan W (2020), Genomic characterisation and epidemiology of 2019 novel coronavirus: implications for virus origins and receptor binding. Lancet 395, 565-574. https://doi.org/10.1016/ S0140-6736(20)30251-8.

5. Zhu N, Zhang D, Wang W, Li X, Yang B, Song J, Zhao X, Huang B, Shi W, Lu R, Niu P, Zhan F, Ma X, Wang D, Xu W, Wu G, Gao GF, Tan W, China Novel Coronavirus Investigating and Research Team (2020), A novel coronavirus from patients with pneumonia in China, 2019. N Engl J Med 382, 727-733. https://doi.org/10.1056/ NEJMoa2001017.

6. Yeager A (2020), Coronavirus's genetics hint at its cryptic spread in communities - Contact tracing and genetic testing reveal how SARS-CoV-2 circulated among individuals for weeks, especially in the US, before being detected. The Scientist, Mar 6, 2020. Available from https://www.thescientist.com/news-opinion/coronaviruss-genetics-hint-atits-cryptic-spread-in-communities-67233. (Accessed March 2020)

7. Scales DC, Green K, Chan AK, Poutanen SM, Foster D, Nowak K, Raboud JM, Saskin R, Lapinsky SE, Stewart TE (2003), Illness in intensive care staff after brief exposure to severe acute respiratory syndrome. Emerg Infect Dis 9, 1205-1210. https://doi.org/10.3201/eid0910.030525.

8. Christian MD, Loutfy M, McDonald LC, Martinez KF, Ofner M, Wong T, Wallington T, Gold WL, Mederski B, Green K, Low DE, SARS Investigation Team (2004), Possible SARS coronavirus transmission during cardiopulmonary resuscitation. Emerg Infect Dis 10, 287-293. https://doi.org/10.3201/eid1002.030700.

9. Luo C, Yao L, Zhang L, Yao M, Chen X, Wang Q, Shen H (2020), Possible transmission of Severe Acute Respiratory Syndrome Coronavirus 2 (SARS-CoV-2) in a Public Bath Center in Huai'an, Jiangsu Province, China. JAMA Netw Open 3, e204583. https://doi.org/10.1001/jamanetworkopen. 2020.4583.

10. American Academy of Otolaryngology Head and Neck Surgery (AAO-HNS) (2020), Anosmia, Hyposmia, and Dysgeusia Symptoms of Coronavirus Disease. March 22, 2020. Available from: https://www.entnet.org/content/ aao-hns-anosmia-hyposmia-and-dysgeusia-symptoms-coronavirus-disease. (Accessed April 2020)

11. Lüers JC, Klußmann JP, Guntinas-Lichius O (2020), The COVID-19 pandemic and otolaryngology: What it comes down to? Laryngorhinootologie. https://doi.org/10.1055/ a-1095-2344.

12. Hopkins C, Kumar N (2020), Loss of sense of smell as marker of COVID-19 infection, The British Association of Otorhinolaryngology, ENT UK at the Royal College of Surgeons of England. April 4, 2020. Available from: https://www.entuk. org/sites/default/files/files/Loss\%20of\%20sense\%20of\%20 smell\%20as\%20marker\%20of\%20COVID.pdf. (Accessed April 2020).

13. Wu Z, McGoogan JM (2020), Characteristics of and important lessons from the Coronavirus Disease 2019 (COVID-19) outbreak in China: Summary of a report of 72314 cases from the Chinese Center for Disease Control and Prevention. JAMA. https://doi.org/10.1001/jama. 2020.2648 . 
14. Worldometer (2020), Worldometer Coronavirus. Available from: https://www.worldometers.info/coronavirus/. (Accessed March 2020).

15. Wang D, Hu B, Hu C, Zhu F, Liu X, Zhang J, Wang B, Xiang H, Cheng Z, Xiong Y, Zhao Y, Li Y, Wang X, Peng Z (2020), Clinical characteristics of 138 hospitalized patients with 2019 novel coronavirus-infected pneumonia in Wuhan, China. JAMA. https://doi.org/10.1001/jama.2020.1585.

16. Ti LK, Ang LS, Foong TW, Ng BSW (2020), What we do when a COVID-19 patient needs an operation: operating room preparation and guidance. Can J Anaesth. https://doi.org/10.1007/s12630-020-01617-4.

17. Royal College of Surgeons of Edinburgh (2020), Intercollegiate general surgery guidance on COVID-19 update. March 27, 2020, April 02, 2020. Available from https://www.rcsed. ac.uk/news-public-affairs/news/2020/march/intercollegiategeneral-surgery-guidance-on-covid-19-update (Accessed March and April 2020).

18. European Centre for Disease Prevention and Control (ECDC) (2020), Technical Report: Novel coronavirus (SARS-CoV-2). Available from: https://www.ecdc.europa.eu/sites/default/ files/documents/COVID-19-Discharge-criteria.pdf. (Access April 05, 2020).

19. World Health Organization (WHO) (2020), Laboratory testing for coronavirus disease 2019 (COVID-19) in suspected human cases: Interim guidance. 2 March 2020, WHO; 2020 [11 March, 2020]. Available from: https:// www.who.int/publications-detail/laboratory-testing-for2019-novel-coronavirus-in-suspected-human-cases20200117 (Accessed March 2020).

20. Centers for Disease Control (CDC) (2020), Available from https://www.cdc.gov. (Accessed March 2020).

21. Center of Disease Control (CDC) (2020), Interim guidelines for collecting, handling, and testing clinical specimens from persons under investigation (PUIs) for coronavirus disease 2019 (COVID-19). February 14, 2020. Available from https://www.cdc.gov/coronavirus/2019-nCoV/lab/guidelines-clinical-specimens.html (Accessed March 2020).

22. Alhazzani W, Møller MH, Arabi YM, Loeb M, Gong MN, Fan E, Oczkowski S, Levy MM, Derde L, Dzierba A, Du B, Aboodi M, Wunsch H, Cecconi M, Koh Y, Chertow DS, Maitland K, Alshamsi F, Belley-Cote E, Greco M, Laundy M, Morgan JS, Kesecioglu J, McGeer A, Mermel L, Mammen MJ, Alexander PE, Arrington A, Centofanti JE, Citerio G, Baw B, Memish ZA, Hammond N, Hayden FG, Evans L, Rhodes A (2020), Surviving sepsis campaign: guidelines on the management of critically ill adults with coronavirus disease 2019 (COVID-19). Crit Care Med. https://doi.org/10.1097/CCM.0000000000004363.

23. Xu Y, Li X, Zhu B, Liang H, Fang C, Gong Y, Guo Q, Sun X, Zhao D, Shen J, Zhang H, Liu H, Xia H, Tang J, Zhang K, Gong S (2020), Characteristics of pediatric SARS-CoV-2 infection and potential evidence for persistent fecal viral shedding. Nat Med. https://doi.org/10.1038/s41591-0200817-4.

24. Medema G, Heijnen L, Elsinga G, Italiaander R, Brouwer A (2020), Presence of SARS-Coronavirus-2 in sewage, medRIX. https://doi.org/10.1101/2020.03.29.20045880. Available from: https://www.medrxiv.org/content/10.1101/2020. 03.29.20045880v1.

25. Zhou F, Yu T, Du R, Fan G, Liu Y, Liu Z, Xiang J, Wang Y, Song B, Gu X, Guan L, Wei Y, Li H, Wu X, Xu J, Tu S, Zhang Y, Chen H, Cao B (2020), Clinical course and risk factors for mortality of adult inpatients with COVID-19 in Wuhan, China: a retrospective cohort study. Lancet 395, 1054-1062. https://doi.org/10.1016/S0140-6736 (20)30566-3.
26. World Health Organization (WHO) (2020), Laboratory screening testing for 2019 novel coronavirus (2019-nCoV) in suspected human cases. March 19, 2020. Available from: https://www.who.int/publications-detail/laboratory-testing-for-2019-novel-coronavirus-in-suspected-human-cases20200117. (Accessed March 28, 2020).

27. To KK, Tsang OT, Leung WS, Tam AR, Wu TC, Lung DC, Yip CC, Cai JP, Chan JM, Chik TS, Lau DP, Choi CY, Chen LL, Chan WM, Chan KH, Ip JD, Ng AC, Poon RW, Luo CT, Cheng VC, Chan JF, Hung IF, Chen Z, Chen H, Yuen KY (2020), Temporal profiles of viral load in posterior oropharyngeal saliva samples and serum antibody responses during infection by SARS-CoV-2: an observational cohort study. Lancet Infect Dis, https://doi.org/10.1016/S14733099(20)30196-1.

28. European Centre for Disease Prevention and Control (ECDC) (2020), Coronavirus disease 2019 (COVID-19) pandemic: increased transmission in the EU/EEA and the UK - seventh update. 25 March, 2020. Available from: https://www.ecdc.europa.eu/sites/default/files/documents/ RRA-seventh-update-Outbreak-of-coronavirus-diseaseCOVID-19.pdf (Accessed March 2020).

29. Guan WJ, Liang WH, Zhao Y, Liang HR, Chen ZS, Li YM, Liu XQ, Chen RC, Tang CL, Wang T, Ou CQ, Li L, Chen PY, Sang L, Wang W, Li JF, Li CC, Ou LM, Cheng B, Xiong S, Ni ZY, Xiang J, Hu Y, Liu L, Shan H, Lei CL, Peng YX, Wei L, Liu Y, Hu YH, Peng P, Wang JM, Liu JY, Chen Z, Li G, Zheng ZJ, Qiu SQ, Luo J, Ye CJ, Zhu SY, Cheng LL, Ye F, Li SY, Zheng JP, Zhang NF, Zhong NS, He JX, China Medical Treatment Expert Group for Covid19 (2020), Comorbidity and its impact on 1590 patients with Covid-19 in China: A Nationwide Analysis. Eur Respir J. https://doi.org/10.1183/13993003.00547-2020.

30. Department of Health, Rhode Island (2020), 2019-Novel Coronavirus (COVID-19), specimen collection kit instructions. Available from: https://health.ri.gov/publications/ instructions/COVID-19-Specimen-Collection-Kit.pdf. (Accessed April 2020).

31. Bai HX, Hsieh B, Xiong Z, Halsey K, Choi JW, Tran TML, Pan I, Shi LB, Wang DC, Mei J, Jiang XL, Zeng QH, Egglin TK, Hu PF, Agarwal S, Xie F, Li S, Healey T, Atalay MK, Liao WH (2020), Performance of radiologists in differentiating COVID-19 from viral pneumonia on chest CT. Radiology, 200823. https://doi.org/10.1148/radiol.2020200823.

32. RCR (2020), RCR position on the role of CT in patients suspected with COVID-19 infection, The Royal College of Radiologists. Available from:https://www.rcr.ac.uk/college/ coronavirus-covid-19-what-rcr-doing/rcr-position-role-ctpatients-suspected-covid-19 (Accessed March 2020).

33. Expert Panel on Thoracic Imaging, Lee C, Colletti PM, Chung JH, Ackman JB, Berry MF, Carter BW, de Groot PM, Hobbs SB, Johnson GB, Maldonado F, McComb BL, Tong BC, Walker CM, Kanne JP (2019), ACR Appropriateness Criteria ${ }^{\circledR}$ acute respiratory illness in immunocompromised patients. J Am Coll Radiol 16, S331-S339. https://doi.org/10.1016/j.jacr.2019.05.019.

34. Mossa-Basha M, Meltzer CC, Kim DC, Tuite MJ, Kolli KP, Tan BS (2020), Radiology department preparedness for COVID-19: Radiology Scientific Expert Panel. Radiology 16, 200988. https://doi.org/10.1148/radiol.2020200988.

35. ACR (2020), ACR Recommendations for the Use of Chest Radiography and Computed Tomography (CT) for Suspected COVID-19 Infection. American College of Radiology, March 22, 2020. https://www.acr.org/Advocacy-andEconomics/ACR-Position-Statements/Recommendationsfor-Chest-Radiography-and-CT-for-Suspected-COVID19Infection. (Accessed March 2020). 
36. CAR - Canadian Association of Radiologists (2020), Canadian Society of Thoracic Radiology and Canadian Association of Radiologists' Statement on COVID-19. March 26, 2020. Available from https://car.ca/news/canadian-societyof-thoracic-radiology-and-canadian-association-of-radiologists-statement-on-covid-19/ (Accessed March 2020).

37. Li K, Fang Y, Li W, Pan C, Qin P, Zhong Y, Liu X, Huang M, Liao Y, Li S (2020), CT image visual quantitative evaluation and clinical classification of coronavirus disease (COVID-19). Eur Radiol. https://doi.org/10.1007/s00330020-06817-6.

38. Perlman S (2020), Another decade, another coronavirus. N Engl J Med 382, 760-762. https://doi.org/10.1056/ NEJMe2001126.

39. Kanne JP, Little BP, Chung JH, Elicker BM, Ketai LH (2020), Essentials for radiologists on COVID-19: an updateRadiology Scientific Expert Panel. Radiology, 200527. https://doi.org/10.1148/radiol.2020200527.

40. Rodrigues JCL, Hare SS, Edey A, Devaraj A, Jacob J, Johnstone A, McStay R, Nair A, Robinson G (2020), An update on COVID-19 for the radiologist - A British Society of Thoracic Imaging statement. Clin Radiol. https://doi. org/10.1016/j.crad.2020.03.003.

41. Wang K, Kang S, Tian R, Zhang X, Zhang X, Wang Y (2020), Imaging manifestations and diagnostic value of chest CT of coronavirus disease 2019 (COVID-19) in the Xiaogan area. Clin Radiol. https://doi.org/10.1016/j.crad.2020.03.004.

42. Zhou Z, Guo D, Li C, Fang Z, Chen L, Yang R, Li X, Zeng W (2020), Coronavirus disease 2019: initial chest CT findings. Eur Radiol. https://doi.org/10.1007/s00330-020-06816-7.

43. Cheng Z, Lu Y, Cao Q, Qin L, Pan Z, Yan F, Yang W (2020), Clinical features and chest CT manifestations of Coronavirus Disease 2019 (COVID-19) in a single-center study in Shanghai, China. AJR Am J Roentgenol 1-6. https://doi.org/10.2214/AJR.20.22959.

44. Zhu W, Xie K, Lu H, Xu L, Zhou S,Fang S (2020), Initial clinical features of suspected coronavirus disease 2019 in two emergency departments outside of Hubei, China. J Med Virol. https://doi.org/10.1002/jmv.25763.

45. General Office of National Health Committee, Office of State Administration of Traditional Chinese Medicine (2020), Notice on the issuance of a program for the diagnosis and treatment of novel coronavirus (2019$\mathrm{nCoV}$ ) infected pneumonia (trial fifth edition) (202002-26).

46. General Office of National Health Committee, Office of State Administration of Traditional Chinese Medicine (2020), Notice on the issuance of a program for the diagnosis and treatment of novel coronavirus (2019-nCoV) infected pneumonia (trial sixth edition) (2020-02-19).

47. Fang Y, Zhang H, Xie J, Lin M, Ying L, Pang P, Ji W (2020), Sensitivity of chest CT for COVID-19: comparison to RT-PCR. Radiology 200432. https://doi.org/10.1148/ radiol.2020200432.

48. Ai T, Yang Z, Hou H, Zhan C, Chen C, Lv W, Tao Q, Sun Z, Xia L (2020), Correlation of chest CT and RT-PCR testing in Coronavirus Disease 2019 (COVID-19) in China: A report of 1014 cases. Radiology, 200642. https://doi.org/ 10.1148/radiol.2020200642.

49. Bernheim A, Mei X, Huang M, Yang Y, Fayad ZA, Zhang N, Diao K, Lin B, Zhu X, Li K, Li S, Shan H, Jacobi A, Chung M (2020), Findings in coronavirus disease-19 (COVID-19): relationship to duration of infection. Radiology 20, 200463. https://doi.org/10.1148/radiol.2020200463.

50. Biccard BM (2005), Relationship between the inability to climb two flights of stairs and outcome after major noncardiac surgery: implications for the pre-operative assess- ment of functional capacity. Anaesthesia 60, 588-593. https://doi.org/10.1111/j.1365-2044.2005.04181.x.

51. Klapsa K (2020), Wir können nicht jeden testen, der leicht hustet, Welt. February 28, 2020. Available from: https:// www.welt.de/politik/deutschland/article206205199/ Bundesaerztekammer-Wir-muessten-alle-Operationenverschieben-die-kein-Notfall-sind.html. (Accessed February 2020).

52. Brindle M, Gawande A (2020), Managing COVID-19 in surgical systems. Ann Surg. https://doi.org/10.1097/ SLA.0000000000003923.

53. Deutsche Bundesregierung (2020) Sozialkontakte vermeiden, Ausbreitung verlangsamen, March 12, 2020. Available from: https://www.bundesregierung.de/breg-de/themen/ coronavirus/mpk-1730186. (Accessed March 2020).

54. Luthi S (2020), Surgeon General advises hospitals to cancel elective surgeries, Mar 14, 2020: Available from https://www. politico.com/news/2020/03/14/surgeon-general-electivesurgeries-coronavirus-129405. (Accessed March 2020).

55. Centers for Medicare \& Medicaid Services (CMS) (2020), CMS Adult Elective Surgery and Procedures Recommendations: Limit all non-essential planned surgeries and procedures, including dental, until further notice. March 18, 2020. Available from: https://www.cms.gov/files/document/31820cms-adult-elective-surgery-and-procedures-recommendations. pdf (Accessed March 2020).

56. American Hospital Association (2020), Coronavirus Update: New Information on Elective Surgery, PPE Conservation and Additional COVID-19 Issues. March 19, 2020. Available from: https://www.aha.org/system/files/media/file/2020/ 03/new-information-on-elective-surgery-ppe-conservationadditional-covid-19-issues-3-18-2020.pdf. (Accessed March 2020).

57. Iacobucci G (2020), Covid-19: all non-urgent elective surgery is suspended for at least three months in England. BMJ 368, m1106. https://doi.org/10.1136/bmj.m1106.

58. American Academy of Otolaryngology Head and Neck Surgery (AAO-HNS) (2020), Policy Statement on Otolaryngologists and the COVID-19 Pandemic. March 23, 2020. Available from: https://www.entnet.org/content/ otolaryngologists-and-covid-19-pandemic (Access March 2020).

59. Tuech JJ, Gangloff A, Fiore FD, Michel P, Brigand C, Slim K, Pocard M, Schwarz L (2020), Strategy for the practice of digestive and oncological surgery during the Covid-19 epidemic. J Vis Surg. https://doi.org/10.1016/j.jviscsurg.2020.03.008.

60. American College of Surgeons (ACS) (2020), COVID-19: Elective case triage guidelines for surgical care. March 24, 2020. Available from: https://www.facs.org/covid-19/clinical-guidance/elective-case. (Accessed March 2020).

61. Australian and New Zealand Hepatic, Pancreatic and Biliary Association (ANZHPBA) (2020), Considerations for HPB Surgeons in a Complex Triage Scenario COVID19. April 06, 2020. Available from https://www.anzhpba. com/covid-19-guidelines/. (Access April 06, 2020).

62. Havens JM, Columbus AB, Seshadri AJ, Brown CVR, Tominaga GT, Mowery NT, Crandall M (2018), Risk stratification tools in emergency general surgery. Trauma Surg Acute Care Open 3, e000160. https://doi.org/10.1136/ tsaco-2017-000160.

63. Saklad M (1941), Grading of patients for surgical procedures. Anesthesiology 2, 281-284. Available from: https:// anesthesiology.pubs.asahq.org/article.aspx?articleid=1973837. (Accessed January 1999).

64. Charlson ME, Pompei P, Ales KL, MacKenzie CR (1987), A new method of classifying prognostic comorbidity in longitudinal studies: development and validation. J Chronic Dis 40, 373-383. https://doi.org/10.1016/0021-9681(87)90171-8. 
65. Copeland GP, Jones D, Walters M (1991), POSSUM: a scoring system for surgical audit. Br J Surg 78, 355-360. https://doi.org/10.1002/bjs.1800780327.

66. Sutton R, Bann S, Brooks M, Sarin S (2002), The Surgical Risk Scale as an improved tool for risk-adjusted analysis in comparative surgical audit. $\mathrm{Br} \mathrm{J}$ Surg 89, 763-768. https://doi.org/10.1046/j.1365-2168.2002.02080.x.

67. Hadjianastassiou VG, Tekkis PP, Poloniecki JD, Gavalas MC, Goldhill DR (2004), Surgical mortality score: risk management tool for auditing surgical performance. World J Surg 28, 193-200. https://doi.org/10.1007/s00268-0037174-6.

68. Donati A, Ruzzi M, Adrario E, Pelaia P, Coluzzi F, Gabbanelli V, Pietropaoli P (2004), A new and feasible model for predicting operative risk. Br J Anaesth 93, 393399. https://doi.org/10.1093/bja/aeh210.

69. Devita MA, Bellomo R, Hillman K, Kellum J, Rotondi A, Teres D, Auerbach A, Chen WJ, Duncan K, Kenward G, Bell M, Buist M, Chen J, Bion J, Kirby A, Lighthall G, Ovreveit J, Braithwaite RS, Gosbee J, Milbrandt E, Peberdy M, Savitz L, Young L, Harvey M, Galhotra S (2006), Findings of the first consensus conference on medical emergency teams, Crit Care Med 34(9), 2463-2478. Erratum in: Crit Care Med 34, 3070. https://doi.org/10.1097/01. CCM.0000235743.38172.6E.

70. Gawande AA, Kwaan MR, Regenbogen SE, Lipsitz SA, Zinner MJ (2007), An Apgar score for surgery. J Am Coll Surg 204, 201-208. https://doi.org/10.1016/j.jamcollsurg. 2006.11.011.

71. Story DA, Fink M, Leslie K, Myles PS, Yap SJ, Beavis V, Kerridge RK, McNicol PL (2009), Perioperative mortality risk score using pre- and postoperative risk factors in older patients. Anaesth Intensive Care 37, 392-398. https://doi. org $/ 10.1177 / 0310057 X 0903700310$.

72. Bilimoria KY, Liu Y, Paruch JL, Zhou L, Kmiecik TE, Ko CY, Cohen ME (2013), Development and evaluation of the universal ACS NSQIP surgical risk calculator: a decision aid and informed consent tool for patients and surgeons. J Am Coll Surg 217, 833-842.e1-3. https://doi.org/10.1016/ j.jamcollsurg.2013.07.385.

73. Protopapa KL, Simpson JC, Smith NC, Moonesinghe SR (2014), Development and validation of the Surgical Outcome Risk Tool (SORT). Br J Surg 101, 1774-1783. https://doi.org/10.1002/bjs.9638.

74. Sangji NF, Bohnen JD, Ramly EP, Yeh DD, King DR, DeMoya M, Butler K, Fagenholz PJ, Velmahos GC, Chang DC, Kaafarani HM (2016), Derivation and validation of a novel Emergency Surgery Acuity Score (ESAS). J Trauma Acute Care Surg 81, 213-220. https://doi.org/10.1097/ TA.0000000000001059.

75. Brady R (2020), Shared experience from China - an interview with Xiaohua Jiang. European Society of Coloproctology. April 02, 2020. Achieved from URL: https:// www.escp.eu.com/news/2084-shared-experience-from-chinaan-interview-with-xiaohua-jiang. (Accessed March 2020).

76. Li CI, Pai JY, Chen CH (2020), Characterization of smoke generated during the use of surgical knife in laparotomy surgeries. J Air Waste Manag Assoc 70, 324-332. https://doi.org/10.1080/10962247.2020.1717675.

77. Zheng MH, Boni L, Fingerhut A (2020), Minimally invasive surgery and the novel coronavirus outbreak: Lessons learned in China and Italy. Ann Surg. https://doi.org/10.1097/ SLA.0000000000003924.

78. Alp E, Bijl D, Bleichrodt RP, Hansson B, Voss A (2006), Surgical smoke and infection control. J Hosp Infect 62, 1-5. https://doi.org/10.1016/j.jhin.2005.01.014.
79. Hoglan M (1995), Potential hazards from electrosurgical plume. Can Operating Room Nurs J 13, 10-16. PMID: 8697285.

80. Ball K (2001), Update for nurse anesthetists. Part 1. The hazards of surgical smoke. AANA J 69, 125-132. PMID: 11759146.

81. Ferenczy A, Bergeron C, Richart RM (1995), Human papillomavirus DNA in $\mathrm{CO} 2$ laser-generated plume of smoke and its consequences to the surgeon. Obstet Gynecol 75, 114-118. PMID: 2153274.

82. Baggish MS, Poiesz BJ, Joret D, Williamson P, Refai A (1991), Presence of human immunodeficiency virus DNA in laser smoke. Lasers Surg Med 11, 197-203. https://doi.org/ 10.1002/lsm.1900110302.

83. Gloster HM Jr, Roenigk RK (1995), Risk of acquiring human papillomavirus from the plume produced by the carbon dioxide laser in the treatment of warts. J Am Acad Dermatol 323, 436-441. https://doi.org/10.1016/0190-9622 (95)90065-9.

84. Carbajo-Rodriguez H, Aguayo-Albasini JL, Soria-Aledo V, Garcia-Lopez C (2009), Surgical smoke: Risks and preventive measures. Cir Esp 85, 274-279. https://doi.org/ 10.1016/j.ciresp.2008.10.004.

85. Fan JKM, Chan FSY, Chu KM (2009), Surgical smoke. Asian J Surg 39, 253-257. https://doi.org/10.1016/S10159584(09)60403-6.

86. Lewin JM, Brauer JA, Ostad A (2011), Surgical smoke and the dermatologist. J Am Acad Dermatol 65, 636-641. https://doi.org/10.1016/j.jaad.2010.11.017.

87. Choi SH, Kwon TG, Chung SK, Kim TH (2014), Surgical smoke may be a biohazard to surgeons performing laparoscopic surgery. Surg Endosc 28, 2374-2380. https://doi.org/ 10.1007/s00464-014-3472-3.

88. In SM, Park DY, Sohn IK, Kim CH, Lim HL, Hong SA, Jung DY, Jeong SY, Han JH, Kim HJ (2015), Experimental study of the potential hazards of surgical smoke from powered instruments. Br J Surg 102, 1581-1586. https://doi.org/10. 1002/bjs.9910.

89. Kwak HD, Kim SH, Seo YS, Song KJ (2016), Detecting hepatitis B virus in surgical smoke emitted during laparoscopic surgery. Occup Environ Med 73, 857-863. https://doi.org/10.1136/oemed-2016-103724.

90. McGoldrick KE (2012), Chapter 1 - Eye, ear, nose, and throat diseases, in: L Fleisher (Ed.), Anesthesia and uncommon diseases, 6th edn, Saunders, pp. 1-27.

91. Royal College of Surgeos (RCS) (2020), Guidance for surgeons working during the COVID-19 pandemic. March 20, 2020. Available from: https://www.rcseng.ac.uk/coronavirus/jointguidance-for-surgeons-v1/ (Accessed March 2020).

92. Pryor A (2020), SAGES and EAES recommendations regarding surgical response to COVID-19 crisis. March 29, 2020. Available from https://www.sages.org/recommendations-surgical-response-covid-19. (Accessed March 2020).

93. Society of American Gastrointestinal and Endoscopic Surgeons (SAGES) (2020), Notes from the battlefield. March 30, 2020. Achieved from: https://www.sages.org/notes-fromthe-battlefield-march-30-2020 (Accessed March 2020).

94. Leung NHL, Chu DKW, Shiu EYC, Chan KH, McDevitt JJ, Hau BJP, Yen HL, Li Y, Ip DKM, Peiris JSM, Seto WH, Leung GM, Milton DK, Cowling BJ (2020), Respiratory virus shedding in exhaled breath and efficacy of face masks. Nature Med. https://doi.org/10.1038/s41591-020-0843-2.

95. Spearman J, Tsavellas G, Nichols P (2007), Current attitudes and practices towards diathermy smoke. Ann R Coll Surg Engl 89, 162-165. https://doi.org/10.1308/ 003588407x155752. 
96. Mowbray N, Ansell J, Warren N, Wall P, Torkington J (2013), Is surgical smoke harmful to theater staff? A systematic review. Surg Endosc 27, 3100-3107. https://doi. org $/ 10.1007 / \mathrm{s} 00464-013-2940-5$.

97. Baron S, Fons M, Albrecht T (1996), Viral pathogenesis, in: S. Baron (Ed.), Medical microbiology, 4th edn., The University of Texas Medical Branch at Galveston, Galveston, TX, Chapter 45. Available from: https://www.ncbi. nlm.nih.gov/books/NBK8149/. (Accessed April 2020).

98. Dellamonica J, Boisseau N, Goubaux B, Raucoules-Aimé M (2004), Comparison of manufacturers' specifications for 44 types of heat and moisture exchanging filters. Br J Anaesth 93, 532-539. https://doi.org/10.1093/bja/aeh239.

99. Kim JM, Chung YS, Jo HJ, Lee NJ, Kim MS, Woo SH, Park S, Kim JW, Kim HM, Han MG (2020), Identification of Coronavirus Isolated from a Patient in Korea with COVID-19. Osong Public Health Res Perspect 11, 3-7. https://doi.org/10.24171/j.phrp.2020.11.1.02.

100. Mintz Y, Arezzo A, Boni L, Chand M, Brodie R, Fingerhut A, and The Technology Committee of the EAES (2020), A low cost, safe and effective method for smoke evacuation in laparoscopic surgery for suspected coronavirus patients. Ann Surg. Apr 06, 2020, E-published aheadof-print.

101. Viswanath A, Monga P (2020), Working through the COVID-19 outbreak: rapid review and recommendations for MSK and allied heath personnel. J Clin Orthop Trauma. https://doi.org/10.1016/j.jcot.2020.03.014.

102. Wong J, Goh QY, Tan Z, Lie SA, Tay YC, Ng SY, Soh CR (2020), Preparing for a COVID-19 pandemic: a review of operating room outbreak response measures in a large tertiary hospital in Singapore. Can J Anaesth. https://doi. org/10.1007/s12630-020-01620-9.

103. Fraser VJ, Johnson K, Primack J, Jones M, Medoff G, Dunagan WC (1993), Evaluation of rooms with negative pressure ventilation used for respiratory isolation in seven midwestern hospitals. Infect Control Hosp Epidemiol 14, 623-628. https://doi.org/10.1086/646654.

104. Zou L, Ruan F, Huang M, Liang L, Huang H, Hong Z, Yu J, Kang M, Song Y, Xia J, Guo Q, Song T, He J, Yen HL, Peiris M, Wu J (2020), SARS-CoV-2 Viral Load in Upper Respiratory Specimens of Infected Patients. N Engl J Med 382, 1177-1179. https://doi.org/10.1056/NEJMc2001737.

105. Leung NHL, Chu DKW, Shiu EYC, Chan KH, McDevitt JJ, Hau BJP, Yen HL, Li Y, Ip DKM, Peiris JSM, Seto WH, Leung GM, Milton DK, Cowling BJ (2020), Respiratory virus shedding in exhaled breath and efficacy of face masks. Nature Med. https://doi.org/10.1038/s41591-020-0843-2.

106. American College of Surgeons (2020), How do I manage surgery for COVID-19 PUI/confirmed patients, Frequently Asked Questions. March 21, 2020. Available from: https:// www.facs.org/covid-19/faqs. (Accessed March 2020).

107. Chen R, Zhang Y, Huang L, Cheng BH, Xia ZY, Meng QT (2020), Safety and efficacy of different anesthetic regimens for parturients with COVID-19 undergoing Cesarean delivery: a case series of 17 patients. Can J Anaesth. https://doi. org/10.1007/s12630-020-01630-7.

108. Government of Canada (2020), Infection prevention and control for novel coronavirus (2019-nCoV): interim guidance for acute healthcare settings. Available from: https:// www.canada.ca/en/public-health/services/diseases/2019novel-coronavirus-infection/health-professionals/interimguidance-acute-healthcare-settings.html. (Accessed March 2020).

109. Wax RS, Christian MD (2020), Practical recommendations for critical care and anesthesiology teams caring for novel coronavirus (2019-nCoV) patients. Can J Anaesth. https://doi.org/10.1007/s12630-020-01591-x.

110. Cook TM, El-Boghdadly K, McGuire B, McNarry AF, Patel A, Higgs A (2020), Consensus guidelines for managing the airway in patients with COVID-19: Guidelines from the Difficult Airway Society, the Association of Anaesthetists the Intensive Care Society, the Faculty of Intensive Care Medicine and the Royal College of Anaesthetists. Anaesthesia. https://doi.org/10.1111/anae.15054.

111. Aerosol Box Evaluation (2020), Watch the Latest Aerosol Box Evaluation, Dr. Hsien Yung Lai calls on plastic fabricators worldwide to supply health care professionals with this cost-effective shield, \#COVID-19. March 22, 2020. Available from: https://www.aerosolblock.org. (Accessed April 2020).

112. Wölfel R, Cormann VM, Guddemos W, Seilmaier M, Zange S, Müller MA, Niemeyer D, Jones TC, Vollmar P, Rothe C, Hoelscher M, Bleicker T, Brünink S, Schneider J, Ehmann R, Zwirglmaier K, Drosten C, Wendtner C (2020), Virological assessment of hospitalized patients with COVID2019. Nature. https://doi.org/10.1038/s41586-020-2196-x.

113. Li Y, Huang X, Yu IT, Wong TW, Qian H (2005), Role of air distribution in SARS transmission during the largest nosocomial outbreak in Hong Kong. Indoor Air 15, 83-95. https://doi.org/10.1111/j.1600-0668.2004.00317.x.

114. Cheung TM, Yam LY, So LK, Lau AC, Poon E, Kong BM, Yung RW (2004), Effectiveness of noninvasive positive pressure ventilation in the treatment of acute respiratory failure in severe acute respiratory syndrome. Chest 126, 845-850. https://doi.org/10.1378/chest.126.3.845.

115. Chang XuH, Rebaza A, Sharma L, Dela Cruz CS (2020), Protecting health-care workers from subclinical coronavirus infection. Lancet Respir Med 8, e13. https://doi.org/ 10.1016/S2213-2600(20)30066-7.

116. Mizumoto K, Kagaya K, Zarebski AChowell G (2020), Estimating the asymptomatic proportion of coronavirus disease 2019 (COVID-19) cases on board the Diamond Princess Cruise ship, Yokohama, Japan, 2020. Euro Surveill 25, https://doi.org/10.2807/1560-7917.ES.2020.25.10.2000180.

117. Moriarty LF, Plucinski MM, Marston BJ, Kurbatova EV, Knust B, Murray EL, Pesik N, Rose D, Fitter D, Kobayashi M, Toda M, Canty PT, Scheuer T, Halsey ES, Cohen NJ, Stockman L, Wadford DA, Medley AM, Green G, Regan JJ, Tardivel K, White S, Brown C, Morales C, Yen C, Wittry B, Freeland A, Naramore S, Novak RT, Daigle D, Weinberg M, Acosta A, Herzig C, Kapella BK, Jacobson KR, Lamba K, Ishizumi A, Sarisky J, Svendsen E, Blocher T, Wu C, Charles J, Wagner R, Stewart A, Mead PS, Kurylo E, Campbell S, Murray R, Weidle P, Cetron M, Friedman CR, CDC Cruise Ship Response Team, California Department of Public Health COVID-19 Team, Solano County COVID-19 Team (2020), Public health responses to COVID-19 outbreaks on cruise ships - Worldwide, February-March 2020. MMWR Morb Mortal Wkly Rep 69, 347-352. https://doi. org/10.15585/mmwr.mm6912e3.

118. Rocklöv J, Sjödin H, Wilder-Smith A (2020), COVID-19 outbreak on the Diamond Princess Cruise ship: estimating the epidemic potential and effectiveness of public health countermeasures. J Travel Med. https://doi.org/10.1093/ $\mathrm{jtm} /$ taaa030.

119. Derrick JL, Gomersall CD (2005), Protecting healthcare staff from severe acute respiratory syndrome: filtration capacity of multiple surgical masks. J Hosp Infect 59, 365368. https://doi.org/10.1016/j.jhin.2004.10.013.

120. Bałazy A, Toivola M, Adhikari A, Sivasubramani SK, Reponen T, Grinshpun SA (2006), Do N95 respirators provide $95 \%$ protection level against airborne viruses, and 
how adequate are surgical masks? Am J Infect Control 34, 51-57. https://doi.org/10.1016/j.ajic.2005.08.018.

121. She J, Jiang J, Ye L, Hu L, Bai C, Song Y (2020), 2019 novel coronavirus of pneumonia in Wuhan, China: emerging attack and management strategies. Clin Transl Med 9, 19. https://doi.org/10.1186/s40169-020-00271-z.

122. Yan Y, Chen H, Chen L, Cheng B, Diao P, Dong L, Gao X, Gu H, He L, Ji C, Jin H, Lai W, Lei T, Li L, Li L, Li R, Liu D,
Liu W, Lu Q, Shi Y, Song J, Tao J, Wang B, Wang G, Wu Y, Xiang L, Xie J, Xu J, Yao Z, Zhang F, Zhang J, Zhong S, Li $\mathrm{H}$, Li H (2020), Consensus of Chinese experts on protection of skin and mucous membrane barrier for health-care workers fighting against coronavirus disease 2019. Dermatol Ther. e13310. https://doi.org/10.1111/dth.13310.

Cite this article as: Brücher B.L.D.M, Nigri G, Tinelli A, Lapeña Jr J.F.F, Espin-Basany E, et al. 2020. COVID-19: Pandemic surgery guidance. 4open, $\mathbf{3}, 1$. 